NBER WORKING PAPER SERIES

\title{
SUSTAINABILITY, DEBT MANAGEMENT, AND PUBLIC DEBT POLICY IN JAPAN
}

\author{
Takero Doi \\ Toshihiro Ihori \\ Kiyoshi Mitsui \\ Working Paper 12357 \\ http://www.nber.org/papers/w12357
NATIONAL BUREAU OF ECONOMIC RESEARCH
1050 Massachusetts Avenue
Cambridge, MA 02138
July 2006

This paper is forthcoming in the book "Fiscal Policy and Management in East Asia" edited by Takatoshi Ito and Andrew Rose. An earlier version of the paper was presented at the $16^{\text {th }}$ Annual East Asian Seminar on Economics held on June 23-25, 2005 and Conference on New Perspective of Fiscal Sustainability, Goethe University Frankfurt Campus Westend, October 13 and 14, 2005. The authors thank Professors Dante Calas, Takatoshi Ito, Anne O. Krueger, Eli Remolona, Andrew Rose, and Jürgen von Hagen, as well as the participants for helpful suggestions. Any remaining errors are our own. The views expressed herein are those of the author(s) and do not necessarily reflect the views of the National Bureau of Economic Research.

(C2006 by Takero Doi, Toshihiro Ihori and Kiyoshi Mitsui. All rights reserved. Short sections of text, not to exceed two paragraphs, may be quoted without explicit permission provided that full credit, including () notice, is given to the source. 
Sustainability, Debt Management, and Public Debt Policy in Japan

Takero Doi, Toshihiro Ihori and Kiyoshi Mitsui

NBER Working Paper No. 12357

July 2006

JEL No. H63, H21, E63

\begin{abstract}
$\underline{\text { ABSTRACT }}$
The purpose of this paper is to analyze sustainability issues of Japan's fiscal policy and then to discuss the debt management policy using the theoretical models and numerical studies. We also investigate the desirable coordination of fiscal and monetary authorities toward fiscal reconstruction.

We include a potential possibilities of the government bonds in our theoretical model. The public bonds, therefore, cannot be sold when the issuance leads the amount of debt outstanding to be more than a certain level. In this respect, the fiscal authority has to take into account the upper limit of stocks of public debt.

This possibility of debt default provides the fiscal authority to issue public bonds strategically in an earlier period. A strategic behavior of fiscal authority induces the monetary authority, in a later period, to boost output and raise seigniorage revenues to eliminate the distortion of resource allocation due to the limitation on debt issuance. Therefore, the monetary policy in a later period suffers from an inflation bias from the ax ante point of view.

There are two ways to eliminate this distortion toward successful fiscal restoration. One of them is to make the monetary authority more conservative than society in the sense that the price stability weight of monetary authority is higher than that of society. The other way of eliminating the distortion of the resource allocation is to design an institutional ceiling on the debt issuance. The direct ceiling can provide a binding constraint of the public bond issuance for the fiscal authority of Japan because it has accumulated the debt outstanding much more than other countries.
\end{abstract}

Takero Doi

Faculty of Economics

Keio University

2-15-45 Mita Minato-ku

Tokyo 108-8345

JAPAN

tdoi@econ.keio.ac.jp

Toshihiro Ihori

Department of Economics

University of Tokyo

7-3-1 Hongo Bunkyo-ku

Tokyo 113-0033

JAPAN

ihori@e.u-tokyo.ac.jp
Kiyoshi Mitsui

Faculty of Economics

Gakushuin University

1-5-1 Mejiro Toshima-ku

Tokyo 171-8588

JAPAN

kiyoshi.mitsui@gakushin.ac.jp 


\section{Introduction}

Currently it is crucial for the Japanese government to implement tight public debt policy, because the Japanese government has issued a very huge amount of government debts. Japan's fiscal situation has deteriorated rapidly with the collapse of the 'bubble economy' in the early 1990s and the deep and prolonged period of economic recession which ensued, and from which recovery has been slow and modest despite the implementation of counter-cyclical Keynesian policy. Since national income did not grow much, tax revenue did not increase either. On the contrary, government spending has been gradually raised due to political pressures of interest groups, resulting in large budget deficits.

In 1997, the Japanese government tried to implement the Fiscal Structural Reform so as to reduce budget deficits. However, in 1998, it stopped the reform and reduced taxes and increased public investment based on the traditional Keynesian policy because of the severe economic and financial situation, and the defeat of the governing party (the Liberal Democratic Party) in the Upper House election.

The concern for sustainability of fiscal deficits is a background for the fiscal reconstruction and structural reform movement by the current Koizumi Administration. The "Structural Reform of the Japanese Economy: Basic Policies for Macroeconomic Development" was decided upon after acceptance of the report compiled by the Council on Economic and Fiscal Policy, an advisory council to the Prime Minister. In this report the core of policies for the structural reform of the economic society was made clear. In part of the policies shown, a goal to limit the amount of government bond issues to less than 30 trillion yen in the fiscal 2002 budget, and afterwards to achieve a primary surplus, was set to show that there exists a necessity to take on full-scale measures towards fiscal consolidation or fiscal reconstruction. However, in order to cope with the bad situation of macro-economy, 1.8 trillion yen of the advance tax cuts was employed with a view to strengthening the competitiveness of industry, facilitating a smooth transference of assets to the next generation, promoting a shift from "saving to investment", advancing effective land use, and so on. The goal to limit the amount of government bond issues to less than 30 trillion yen in the fiscal 2002 budget was finally abandoned. In the fiscal 2005, new government bond issues are 34.4 trillion yen and the bond dependency ratio rises to $41.8 \%$.

If creditors fear that the government is going to be in a debt trap, the long-term interest rate begins to rise, reflecting an enlarged credit risk. It is noted that although the Japanese Government Bonds (JGBs) have been issued too much, 
their yields are the lowest among G7 countries in the bond market. In this regard, despite its weakening credit ratings, the 10 -year JGB nominal yield of about $1.5 \%$ in 2005 remains lower than the U.S. bond yield of about $1.8 \%$ registered during the Great Depression. However, we also have to pay attention to persistent deflation. Also, the performance in the yield of the JGBs may not accurately reflect its credit risk. The Japanese banking sector continues to purchase the JGBs simply because short-term capital gains from the JGBs have been an easy option to offset the existing stock losses.

The purpose of this paper is to analyze sustainability issues of Japan's fiscal policy and then to discuss the debt management policy using theoretical models and numerical studies. We also investigate the desirable coordination of fiscal and monetary authorities toward fiscal reconstruction.

This paper consists of five sections. In section 2 we survey previous studies on sustainability issues. In section 3, we evaluate Japan's debt management policy by providing a theoretical model to analyze public debt policy in a second best case as a benchmark. We then implement a simple numerical analysis based on the smoothing rule derived by the theoretical model. In section 4 , we discuss the desirable coordination of monetary and fiscal authorities towards fiscal reconstruction by explicitly investigating confidence crisis of government debt and spontaneous default of fiscal authority. Finally, concluding remarks follow in Section 5.

\section{Sustainability Issues and Emergency Reform}

\subsection{Concerns about sustainability}

The events of the 1980s and 1990s in Japan suggest that when a government becomes strapped for funds, it will tend to borrow from the world credit market rather than raise taxes to finance additional public spending. Indeed, many governments did either not raise broadly based taxes, e.g., the Thatcher government in Great Britain or the Reagan and Bush Administrations in the United States, or simply could not raise taxes to prevent causing riots, e.g., countries in Latin American and Eastern Europe, and, arguably, France in the reign of Louis XVI. There are long-term concerns about the accumulated fiscal deficit. Important one is whether such a large deficit can be sustained. The system will be paralyzed if public finance collapses under the weight of massive deficit. As a result, the financial system and the economy as a whole will be seriously affected. An extreme case of hyperinflation or default could develop. 
The so-called chain-letter mechanism (or a Ponzi debt game) involves a situation where the future time path of taxes is fixed and debt finance is used to pay for any additional public spending; debt issuance is thus endogenously determined by the government's budget constraint. If the mechanism is sustainable, increased taxation need not necessarily be required in order to finance increased government spending as the economy converges to the steady state equilibrium. If the mechanism is unsustainable, the government will eventually go bankrupt in the sense that it will be unable to raise enough revenue to finance public spending and debt repayment. As debt crowds out private capital formation, the economy will also eventually go bankrupt if the mechanism fails. This suggests that studying the chain-letter mechanism and associated sustainability issues is quite important in terms of understanding the effects of government austerity (fiscal reconstruction) measures on the macroeconomy.

A simple way to evaluate the fiscal sustainability problem is to focus on the government bond market. In this regard for Japan, despite its weakening credit ratings, the 10-year Japanese Government Bond (JGB) nominal yield of about 1.5\% in 2005 remains. So far the myth that the JGBs are risk-free has been somehow propagated. This episode may imply that Japan's government solvency is not a serious issue right now. However, Japan has experienced deep deflation, so the real rate of interest is about $2 \%$, which is not so low. We also have to pay attention to the possibility that the performance in the yield of the JGB may not accurately reflect its credit risk.

Ihori, Nakazato, and Kawade (2002) attempt a standard approach to test the fiscal sustainability condition, using the methodology of Hamilton and Flavin (1986). Hamilton and Flavin (1986) define the sustainability of government debt as follows. Government budget constraint in period $t$ is expressed as

$$
G_{t}+\left(1+r_{t}\right) D_{t}=R_{t}+D_{t+1}
$$

where $G_{t}, R_{t}, r_{t}$, and $D_{t}$ denote aggregate real government expenditure (excluding interest payment), aggregate real tax revenue, real interest rate, and aggregate real bonds outstanding (at the beginning of period), respectively. We can rewrite as

$$
B_{t+1}=E_{t}\left[\sum_{i=1}^{n}\left\{\prod_{j=1}^{i}\left(\frac{1}{1+r_{t+j}}\right)\right\} S_{t+i}\right]+E_{t}\left[\prod_{j=1}^{n}\left(\frac{1}{1+r_{t+j}}\right) B_{t+n+1}\right]
$$

where primary surplus $S_{t} \equiv R_{t}-G_{t}$.

Hamilton and Flavin (1986) define the government budget satisfies

$$
\lim _{n \rightarrow \infty} E_{t}\left[\prod_{j=1}^{n}\left(\frac{1}{1+r_{t+j}}\right) D_{t+n+1}\right]=0
$$

as the condition of sustainability of government bond. The above Equation means 
no Ponzi game condition in dynamic macroeconomic models. Therefore we can confirm the sustainability of government bond by testing the following $A$ is significantly equal to 0 ;

$$
\lim _{n \rightarrow \infty} E_{t}\left[\prod_{j=1}^{n}\left(\frac{1}{1+r_{t+j}}\right) D_{t+n+1}\right]=A \quad A \text { : constant }
$$

Hamilton and Flavin (1986) estimate the following regression to test the sustainability;

$$
D_{t}=c_{0}+A(1+r)^{t}+c_{1} D_{t-1}+\cdots+c_{p} D_{t-p}+d_{1} S_{t-1}+d_{2} S_{t-2}+\cdots+d_{p} S_{t-p}+\varepsilon_{t}
$$

where $\varepsilon_{t}$ denotes a error term. They assume that (expected) real interest rate is constant over time, and expectations and error terms of the regression satisfy the relation that the term of $E_{t}\left[\sum_{i=1}^{\infty}\left(\frac{1}{1+r}\right)^{i} S_{t+i}\right]$ depends on $S_{t-1}, S_{t-2}, \ldots, S_{t-p}$, serial correlation of error terms is eliminated by using the variables, $D_{t-1}, D_{t-2}, \ldots, D_{t-p}$. If the estimator of $A$ in the above equation is significantly equal to 0 , they conclude the government bond is sustainable.

Ihori, Nakazato, and Kawade (2002) conduct the empirical analysis for the Japanese fiscal data from 1957 to 1999 . To conduct the test, the values for the nominal growth rate, $n$, and the nominal interest rate, $r$, must be specified. Their strategy is to set various values for $r-n$ and to check whether the results are sensitive to the values chosen. The estimated results imply that the null hypothesis cannot be rejected at a 5\% significance level, suggesting that government solvency was not a serious problem until fiscal 1996. On the contrary, the result for the period 1957-1997 rejects the null hypothesis when $r-n$ is above 0.05 , and the results for the period 1957-1998 and the period 1957-1999 also reject the null hypothesis when $r-n$ is above 0.04 .

Bohn (1998) proposes a new method different from existing tests for sustainability of government debt. According to Bohn (1998), the test has better properties than the tests based on estimating a transversality condition and on cointegration tests. The condition that fiscal policy satisfies the intertemporal budget constraint, i.e. the condition on sustainability of government debt, is that the primary surplus to GDP $\left(s_{t}\right)$ increases with the ratio of (start-of-period) debt to GDP $\left(d_{t}\right) .{ }^{1} \quad$ Strictly speaking, when we can express a relation between the two as

\footnotetext{
${ }^{1}$ Broda and Weinstein (2005) point out that using gross debt levels to assess Japan's fiscal sustainability is equivalent to treating Japan's financial assets as worthless. They assert, therefore, that net debt levels are more appropriate to assess the fiscal sustainability than gross debt. However, there seem to be following aspects to be considered.

Firstly, Broda and Weinstein (2005) calculate the value of net debt of the Japanese
} 


$$
s_{t}=f\left(d_{t}\right)+\mu_{t}
$$

Suppose other determinants, $\mu_{t}$, is bounded and the present value of future GDP is finite. Then, government debt satisfies a transversality condition if there is a debt-GDP ratio $d^{*}$ such that $f^{\prime}\left(d_{t}\right) \geq \beta>0$ for all $d_{t} \geq d^{*}$, where $\beta$ is a positive constant. We draw a scatter plot of $s_{t}$ against $d_{t}$ in Figure 1 (only the general account of the central government) and Figure 2 (the consolidated account of the central and local governments). Until the early 1990s, the Japanese fiscal policy held the quadratic relation between the two. Recently, the Japanese fiscal policy deviates from the relation excessively. Doi and Ihori (2003) show that Japanese government debt does not satisfy a transversality condition for fiscal $1965-2000$ by estimating $\beta$.

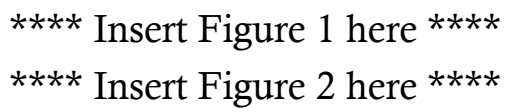

These observations indicate that fiscal sustainability may become a serious issue. The longer the sample period, the more likely we face the fiscal crisis. It follows that the chain letter mechanism will cause the public debt crisis to occur in the near future. Japan has two serious difficulties in terms of sustainability. First, the Japanese primary surplus is apparently a decreasing function of the debt-GDP ratio since 1990 and hence it does not satisfy Bohn's test. Second, the rate of interest is greater than the growth rate in Japan in the 1990s. Hence, it is important to reduce the government deficit in the near future.

\subsection{Non-Keynesian Effect}

Many governments prefer to rely on the issuance of debt rather than explicit taxation in financing expenditures. Recent experience suggests that a number of countries are facing potential bankruptcy as a result of issuing too much debt. As shown in Ihori (1988), the chain-letter mechanism would most likely be sustainable when the initial interest rate and stock of government debt are smaller

public sector by summing together the net debts of the Japanese government, postal savings, and government financial institutions. Though this net debt of the Japanese public sector includes net debt of social security, the assets of social security accounts are earmarked for the future pension benefit payouts. Therefore, it is better, from this aspect, to exclude net debt of social security to assess the fiscal sustainability.

Secondly, if fiscal authority and monetary authority act non-cooperatively, fiscal authority has to take into account the possibility that the monetary authority sell government bonds independently. Therefore, it is important for the independent fiscal authority to assess the fiscal sustainability without taking account of the government bonds held by the monetary authority. Our analysis mainly deals with a non-cooperative case so that we focus our attention on gross debt levels. 
or when the propensity to save and the growth rate are higher.

When the government goes eventually bankrupt, austerity measures as fiscal reconstruction will be required. This will depend critically on the response of the private sector to the specific austerity policy and more specifically the response of capital accumulation. Serious mistakes, which will possibly exacerbate the bankruptcy problem, may occur if the wrong action is taken. The conventional wisdom suggests that either the government must raise taxes or dramatically reduce spending. This is contingent on an increase in capital accumulation taking place in response to the change in policy. However, whether these contractions will be affected through cuts in spending or increases in explicit tax collections, and when these actions will be taken is in general unknown. Expectations of future policy changes are crucial in understanding seemingly counterintuitive macroeconomic dynamics. Bertola and Drazen (1993) argue that expectations about the discrete character of future fiscal adjustments can help explain the effects of current fiscal policy. They showed that if government spending follows an upward-trending stochastic process which the public believes may fall sharply when it reaches specific 'trigger' points, then optimizing consumption behavior and simple budget-constraint arithmetic imply a nonlinear relationship between private consumption and government spending.

The so called "non-Keynesian" effect means that cuts in public expenditures and/or tax increases contribute to stimulate private demand under some fiscal situations or macroeconomic environments: that is, when government spending is inefficient and/or the budget deficit is so large, this paradoxical effect may occur. If this is the case, it becomes possible to attain simultaneously two policy objectives of fiscal reconstruction and macroeconomic recovery. This possibility of so-called non-Keynesian effect is consistent with the experience of several countries.

Such a situation might be relevant for the recent Japanese economy. A recent line of economic research suggests that private agents realize that current bond-financed deficits carry with them future tax obligations. Anticipating higher future taxes, private agents change current spending behavior to smooth consumption intertemporally. Although the econometric study of this issue is still in its infancy, some recent research indicates that private Japanese behavior has partially offset recent changes in fiscal policy (see Ihori and Sato (2002) among others).

\subsection{Emergency reform for debt repudiation}

In reality, however, it may be difficult to employ the standard austerity 
measures in a proper time. For example, Japan's fiscal policy in the 1990s created a problem of a tendency to postpone fiscal reconstruction reforms. The consensus at the time was that there was no immediate need for such painful measures as long as government policy prevented the economy from slipping into recession. There was, indeed, a widespread feeling in the private sector that the government would come to its aid if the economic situation worsened. That feeling fostered certain complacency in the business world, making many corporate managers liable to "moral hazards" - risks stemming from lack of self-discipline. The continuation of the short-term stimulus policy, at a time when the economy needed long-term structural changes, discouraged self-help efforts in the private sector. Lobbying activities of local interest groups was exaggerated in the 1990s, as showed in Ihori, Doi and Kondo (2001) and Doi and Ihori (2002)'s empirical evidence. This is also one of the main reasons why Japan's fiscal reconstruction did not perform very well in the 1990s.

It is thus argued that if the current deficits seem not sustainable, governments in such countries will be forced to in effect repudiate their debt, either explicitly through an introduction of partial default or through inflation depreciation (inflationary taxes). We may call such a policy change the emergency reform for debt repudiation. The consequent fiscal reconstruction postponement is not free from credibility problems: Will the additional debt be paid off in full, or will the government find it optimal to resort to higher inflation or partial default to diminish the burden of the debt, etc? It should be stressed that if the private sector recognizes such possibilities of future emergency reforms for debt repudiation, government bonds and real capital may no longer be regarded as perfect substitutes. The more likely the current deficits seem not sustainable, the higher the subjective probability of the future emergency reform.

\subsection{Literature on debt Ponzi games under uncertainty}

Several important papers investigated debt Ponzi games under uncertainty. The average riskless rate may be a poor guide as to whether permanent rollover of debt is feasible when economies are stochastic. Tirole (1985) and Weil (1987a) examine in the overlapping generations framework deterministic and speculative bubbles which are, like government debt, intergenerational schemes based on trust. Weil considered a two-state model with real capital and a bubble. The bubble has probability $\theta$ of bursting every period. The main result in Weil is that the highest sustainable bubble (the equivalent of the highest sustainable debt in the present paper) decreases with the probability of bursting (debt repudiation). Calvo (1988) 
studies models in which debt repudiation is possible and showed that expectations may play a crucial role in the determination of equilibrium. See also Chari and Kehoe (1993), and Bulow and Rogoff (1989).

Blanchard and Weil (1992) show that whether or not governments can rollover debt in dynamically efficient economies depends on whether the issuance of public debt can partially substitute missing markets. Bohn (1991) shows that the sustainability even of simple policy rules like balanced budgets or tax rate smoothing should not be taken for granted in a stochastic economy and that sustainability is often sensitive to assumptions about debt management. Alesina, Prati and Tabellini (1989) show that the maturity structure of public debt may influence the likelihood of a confidence crisis on the debt. The shorter and more concentrated is the maturity, the more likely is a confidence crisis. See also Giavazzi and Pagano (1989).

\subsection{Remarks}

Economic theory has begun to catch up with political reality. It has done this by not only studying the optimality of fiscal policy in a context where explicit account is taken of the government's budget constraint but it has gone a step further by examining the time consistency of optimal policy. Here, it is the issue of whether it is optimal to keep promises that were optimal to make in the past. The latter lies at the heart of the credibility dilemma faced by any serious politician.

Fiscal regimes differ across countries and change over time. At each point in time there is uncertainty about the regime that will prevail from then on. A high government deficit financed by debt can be regarded as unsustainable and therefore may be taken to signal future contractions in the deficits. The fiscal regime prevailing in an economy, as well as the type of fiscal relationships expected to arise from such a regime, is an important factor in determining the response of private agents to fiscal signals.

The sustainability question in stochastic models is an aspect of fiscal policy that deserves more attention in future research and in policy-making.

\section{Debt Management Policy of the Japanese Government}

\subsection{Japan's Government Bonds}

The Japanese government currently issues government bonds, which can be classified into six categories: short-term (6-month and 1-year Treasury bills); medium-term (2-year and 5-year bonds); long-term (10-year bonds); super-long-term 
(15-year, 20-year and 30-year bonds); government bonds for individual investors; and inflation-indexed bonds. The short-term government bonds are all discount bonds. On the other hand, all medium-, long-, and super-long-term government bonds, except for the 15-year floating-rate bonds, are the bonds with fixed-rate coupons. The 15-year floating-rate bonds and the government bonds for individual investors feature a coupon rate that varies according to certain rules. The inflation-indexed bonds are issued as the 10-years bonds to finance funds for the Fiscal Investment and Loan Program. ${ }^{2}$

The planned issue amount of each JGB for fiscal 2006 is shown in Table 1. In the past, there used to be some other types of government bonds. But after the August 1988 3-year fixed-rate bonds, the September 2000 5-year discount bonds, the February 2001 4-year fixed-rate bonds, the March 2001 6-year fixed-rate bonds, and the November 2002 3-year discount bonds, these bonds have never been issued. The current maturity structure of the government bonds (outstanding basis) is shown in Figure 3.

**** Insert Table 1 here $* * * *$

$* * * *$ Insert Figure 3 here $* * * *$

\subsection{Theoretical Analysis of Debt Management Policy}

We construct a theoretical model based on Beetsma and Bovenberg (1997a, 1997b). We include potential possibilities of the government bonds in the model in Section 4. There are households, firms, the fiscal authority (government) and the monetary authority (central bank). The households live for two periods. The firms produce a private good by using labor, at given price level, $P_{t}(t=1,2)$. Their production functions are $Y_{t}=L_{t}{ }^{\eta} \quad(0<\eta<1)$, where $Y_{t}$ denotes output, $L_{t}$ denotes input of labor. Their profits are described as $\left(1-\tau_{t}\right) P_{t} L_{t}{ }^{\eta}-W_{t} L_{t}$, where $W_{t}$ denotes nominal wage rate. The firms' output is taxed at a rate $\tau_{t}$, as will be described later.

The households organize labor unions, the objective of which is to obtain a target real wage rate. They are assumed to make an expectation to inflation rationally. We also assume that the unions have monopoly power in the labor

\footnotetext{
2 The Fiscal Investment and Loan Program (FILP) has been called "the second budget" because the government initially used FILP to undertake projects it was unable to include in the general account budget. Doi and Hoshi (2003) have a good summary of the structure, components, and history of FILP and PSS, and provide estimates of the costs FILP has and might impose on Japanese taxpayers; its appendix provides a further review of the literature. Also see Cargill and Yoshino $(2000,2003)$.
} 
market. We can normalize the logarithm of real wage rate to zero. Therefore, the (log of the) nominal wage rate is set equal to the (rationally) expected price level.

Under such a situation, the logarithm of output $y_{t} \equiv \ln Y_{t}$ is written as

$$
y_{t}=\frac{\eta}{1-\eta}\left(\pi_{t}-\pi_{t}^{e}-\tau_{t}+\ln \eta\right) .
$$

where $\pi_{t} \equiv \frac{P_{t}-P_{t-1}}{P_{t}}, \pi_{t}^{e}$ denotes the inflation rate expected by the private sector.

Since $\frac{\eta}{1-\eta} \ln \eta$ is a constant, we set $v \equiv \frac{\eta}{1-\eta}$, and normalize $y_{t}$ as follows

$$
x_{t} \equiv y_{t}-v \ln \eta=v\left(\pi_{t}-\pi_{t}^{e}-\tau_{t}\right)
$$

Equation (1) is the Lucas supply function.

In a rational expectations equilibrium $\left(\pi_{t}=\pi_{t}^{e}\right)$, if there exist no tax distortion $\left(\tau_{t}=0\right)$, the normalized output is given as $x_{t}=0$. This normalized output level corresponds to the natural rate of employment, as mentioned in Fujiki et al. (1998). Moreover, the socially desirable output, $\tilde{x}_{t}$, without any distortion of resource allocation is positive, because the socially desirable employment is allowed to exceed the natural rate of employment, as pointed out in Beetsma and Bovenberg $(1997 \mathrm{a}, 1997 \mathrm{~b})$. Hereafter $\tilde{x}_{t}$ is assumed to be given as a positive constant exogenously.

Next, we describe behavior of the monetary authority. The monetary authority decides level of money supply in each period. We presume that the quantity theory of money is held; ${ }^{3}$

$$
\frac{M_{t}}{P_{t}}=\kappa \tilde{X}_{t}
$$

where $\kappa$ is a constant, $M_{t}$ denotes nominal money supply, and $\tilde{X}_{t} \equiv \exp \left(\tilde{x}_{t}\right)$. Since $\tilde{X}_{t}$ is given exogenously, the monetary authority determines the inflation rate directly through controlling money supply. Therefore, $\frac{M_{t}-M_{t-1}}{M_{t}}=\pi_{t}$ in this model.

Finally, we consider the government's behavior. The government (or fiscal authority) collects revenues from taxes, bond issuing and seigniorage. Its revenues are used for fiscal expenditures and repayment of government bond. The

\footnotetext{
${ }^{3}$ An economy in Japan is now mired in a liquidity trap. We would like to focus on the situation where an economy in Japan escapes from a liquidity trap.
} 
government can issue (inflation-indexed) bonds. We assume that the government can issue only one-period bond and the pure expectation hypothesis of interest rate is held. In such a situation, the fiscal authority faces the following budget constraint in each period;

$$
\begin{aligned}
& P_{1} G_{1}+\left(1+r_{B 1}\right) P_{1} B_{0}=\tau_{1} P_{1} X_{1}+\left(M_{1}-M_{0}\right)+P_{1} B_{1} \\
& P_{2} G_{2}+\left(1+r_{B 2}\right) P_{2} B_{1}=\tau_{2} P_{2} X_{2}+\left(M_{2}-M_{1}\right)
\end{aligned}
$$

where $G_{t}$ denotes real government expenditures, $r_{B t}$ denotes interest rate of bonds in period $\mathrm{t}$, and $B_{t}$ denotes the outstanding bonds at the end of period t. $B_{0}$, outstanding bond at the end of period 0 , is exogenously given for the government. The government chooses $G_{t}, \tau_{t}$, and $B_{t}$.

Dividing both sides of the above budget constraints by $P_{t} \tilde{X}_{t}$ gives the following budget constraints in share of non-distortionary (normalized) output:

$$
\begin{aligned}
& g_{1}+\left(1+r_{B 1}\right) b_{0}=\tau_{1}+\kappa \pi_{1}+b_{1} \\
& g_{2}+\left(1+r_{B 2}\right) b_{1}=\tau_{2}+\kappa \pi_{2}
\end{aligned}
$$

where $g_{t} \equiv \frac{G_{t}}{\tilde{X}}, \quad b_{t} \equiv \frac{B_{t}}{\tilde{X}}$. We presume that $X_{t} \approx \tilde{X}_{t} \approx \tilde{X}$ (a constant).

For simplicity, the real interest rate is assumed to be equal to the world interest rate $\rho$, which is constant over time. Hence $r_{B t}=\rho$. From $(2-1,2)$ we can obtain the integrated government budget constraint as follows,

$$
g_{1}+\frac{g_{2}}{1+\rho}+(1+\rho) b_{0}=\tau_{1}+\kappa \pi_{1}+\frac{\tau_{2}+\kappa \pi_{2}}{1+\rho}
$$

\subsection{Second Best Solution}

In this subsection, we analyze the most desirable case with distortionary taxes, where the two policy makers are integrated and are committed to their policy announcements. We deal with the situation in which the government and the central bank are integrated and are credibly committed to their policy announcements. The credible commitment particularly implies that the policy makers announce an inflation rate and commit themselves to the announced rate at the beginning of each period before nominal wages are concluded.

The society has the social loss function $\mathrm{V}^{\mathrm{S}}$, which is represented by

$$
\mathrm{V}^{\mathrm{S}}=\frac{1}{2} \sum_{t=1}^{2} \beta_{S}^{t-1}\left[\alpha_{\pi S} \pi_{t}^{2}+\left(x_{t}-\tilde{x}\right)^{2}+\alpha_{g S}\left(g_{t}-\tilde{g}\right)^{2}\right]
$$

where $\alpha_{\pi S}>0, \alpha_{g S}>0$, and $\beta_{S}$ denotes the discount factor, $0<\beta_{S} \leq 1$. We define $\tilde{g}_{t}$ as the government spending target as the optimal share of the output realized without tax distortions or inflation surprises in period t. Now, for simplicity of the 
analysis, $\tilde{g}_{t}$ is assumed to be constant over time: $\tilde{g}_{t}=\tilde{g}$.

The policy makers minimize the above loss function. The constraints of each period consist of the Lucas supply function (1), the government budget constraint (3), and the restriction generated by the rational expectations formation of the private sector $\left(\pi_{t}^{e}=\pi_{t}\right)$. The optimality conditions are given as follows:

$$
\begin{aligned}
& v^{2}\left(\tau_{t}+\frac{\tilde{x}}{v}\right)=\alpha_{g S}\left(\tilde{g}-g_{t}\right)=\frac{\alpha_{\pi S}}{\kappa} \pi_{t} \quad(\mathrm{t}=1,2) \\
& \pi_{1}=\beta_{S}(1+\rho) \pi_{2} \\
& \tau_{1}+\frac{\tilde{x}}{v}=\beta_{S}(1+\rho)\left(\tau_{2}+\frac{\tilde{x}}{v}\right) \\
& \tilde{g}-g_{1}=\beta_{S}(1+\rho)\left(\tilde{g}-g_{2}\right)
\end{aligned}
$$

Equation (5-1) is the static optimization condition in each period. Equations (5-2), (5-3) and (5-4) are the intertemporal optimization conditions for inflation, tax rate, and government spending, respectively. For example, if $\beta_{S}(1+\rho)=1$ (the discount rate is equal to the rate of interest), it is desirable to have the same levels of inflation, tax rate, and government spending over time, respectively. This is a well known smoothing condition over time a la Barro (1979). See also Barro $(1995,2003)$.

Several remarks are useful. Firstly, as Beetsma and Bovenberg (1997a, 1997b) mention, the social loss is affected by the initial level of government debt outstanding. In the equilibrium, optimal value of $\mathrm{V}^{\mathrm{S}}$ is represented as

$$
V^{S}=\frac{\beta_{S}+\beta_{S}(1+\rho)+(1+\rho) /\left[1+\beta_{S}(1+\rho)^{2}\right]}{\kappa^{2} / \alpha_{\pi S}+1 / v^{2}+1 / \alpha_{g S}}\left\{(1+\rho) b_{0}+\tilde{K}+\frac{\tilde{K}}{1+\rho}\right\},
$$

from (4) and (5). It means that the larger the initial debt $b_{0}$ the larger is the social loss.

Secondly, the income tax and individual preferences of leisure and labor affect the production level of the nation.

Intuition is as follows. To maintain the neutrality of bonds toward social welfare (social loss), it is necessary to issue bonds to cover the part of fiscal expenditures and redemption that cannot be covered from tax revenues and re-coinage profits while maintaining budget constraints and not distorting the inflation rate, tax rate, and fiscal expenditures. Issuing bonds should act as a buffer in the budget.

These results are the same as Beetma and Bovenberg (1997a).

\subsection{Numerical Analysis}

In this subsection, we numerically examine the second best debt 
management policy under commitment, which is theoretically analyzed in the previous subsection. We can easily extend the analytical framework to a more general multi-period model. For the present numerical analysis, we use a 200-period model and incorporate nominal bonds as well. ${ }^{4}$

In doing the numerical analysis, it is necessary to specify values of some exogenous parameters in the theoretical model. Based on the data of Japanese economy, we set $\eta=0.7, \rho=0.04, \beta_{S}=0.964, \alpha_{\pi S}=2, \alpha_{g S}=3, \tilde{x}=0.01$, and $\tilde{g}=$ 0.1. We also adapt $\kappa=0.36$, as mentioned in Fujiki et al. (1998).

We set the initial outstanding debt to (normalized) output ratio as $100 \%$. Under such values of parameters, we derive numerical results by expanding the model to 200 periods. Figure 4 shows transitions of government debt outstanding (to the desirable output ratio) in the upper figure, and inflation rate $(\pi)$, government expenditure (to the desirable output ratio: $g$ ), and tax rate $(\tau)$ in the lower figure. The upper figure suggests that it is desirable to reduce the bond dependence ratio gradually to redeem fully in the 200th period. The lower figure indicates the smoothing effects of these flow variables a la Barro (1979). These figures reflect the smoothing effect.

$* * * *$ Insert Figure 4 here $* * * *$

\section{Debt Management and Fiscal Sustainability}

\subsection{Default of the government bonds}

As analyzed in Beetsma and Bovenberg (1997a, b) among others, when monetary and fiscal authorities are not cooperative and not able to commit their policy announcements, an optimally designed conservative, independent central bank is necessary to establish the second best. The central bank must be made more conservative than society. They showed that correcting monetary policy preferences is a direct way to eliminate the distortions due to the inability to commit. Drudi and Giordano (2000) showed that since default risk increases as the maturity structure of the debt shortens, optimal maturity under bankruptcy risk is in general longer than in the case in which debt repudiation policies can be precommitted or are very much unlikely. See also Persson, Persson and Svensson $(1987,2005)$.

If we allow for political distortions, the preferences of the fiscal authority may depart from the preferences of society. In the presence of political distortions

\footnotetext{
${ }^{4}$ The reason why we set a 200-period model is to weaken effects of the terminal conditions which all stock variables are zero, on this numerical analysis.
} 
a debt target is also needed. For example, if the government discounts the future too heavily, the optimal debt target would de facto act as a ceiling on public debt.

In Japan, the central bank now acts as an independent policy maker and its concern on inflationary targeting is more conservative than the government. In this sense, we could say that the central bank behaves in a good manner to attain the second best.

Let us explain this by including confidence crisis of government debt and spontaneous default of fiscal authority in the model introduced in Section 3. Investors of government bonds decide whether they buy bonds or not in prospect of behaviors of the government. If they can perfectly expect the government's default, they do not purchase bonds at all. Hence we should investigate such a situation using backward induction. It means that a subgame perfect Nash equilibrium is adopted as a solution concept in this section.

The fiscal authority and the monetary authority have individual loss functions. Loss function of the fiscal authority is written as

$$
\mathrm{V}^{\mathrm{F}}=\frac{1}{2} \sum_{t=1}^{2} \beta_{S}^{t-1}\left[\alpha_{\pi F} \pi_{t}^{2}+\left(x_{t}-\tilde{x}\right)^{2}+\alpha_{g S}\left(g_{t}-\tilde{g}\right)^{2}\right]
$$

where $\alpha_{\pi F}>0, \alpha_{g S}>0$, and $\beta_{S}$ denotes the discount factor, $0<\beta_{S} \leq 1$. Also the loss function of the monetary authority is written as

$$
\mathrm{V}^{\mathrm{M}}=\frac{1}{2} \sum_{t=1}^{2} \beta_{S}^{t-1}\left[\alpha_{\pi M} \pi_{t}^{2}+\left(x_{t}-\tilde{x}\right)^{2}+\alpha_{g S}\left(g_{t}-\tilde{g}\right)^{2}\right]
$$

where $\alpha_{\pi M}>\alpha_{\pi F}>0$. It implies that the monetary authority is more conservative in inflation than the fiscal authority. Each policy maker minimizes the above loss function, taking policies selected by the other authority as given. In this section, we set that both policymakers decide policies simultaneously in each period. Investors of the government bonds have the loss function (4).

Now, we describe a situation that the government triggers a debt default. The government can declare the default before policies are chosen in this period. When the default occurs, the government does not pay at all. ${ }^{5}$ However, the production in this economy is deteriorated due to the default. In this situation, the Lucas supply function is assumed to include default costs.

$$
x_{t}=z v\left(\pi_{t}-\pi_{t}^{e}-\tau_{t}\right) \quad 0<z<1
$$

where $z$ is constant over time. It means that the production in default on the government bond is $z$ times as large as that in the normal situation, regardless of the

\footnotetext{
5 The real interest rate is assumed to be equal to the world interest rate. In addition, we exclude the possibility of partial default by assumption. If, therefore, investors expect the default, the interest rate on the government bonds becomes infinity.
} 
amount of the debt.

The constraints of each period consist of the Lucas supply function (1) or (1'), the government budget constraints (2). We also rewrite the government budget constraints as follows,

$$
\begin{aligned}
& \tilde{K}+\frac{(1-z) \tilde{x}}{v z}+(1+\rho) b_{0}=\left(\tau_{1}+\frac{\tilde{x}}{v z}\right)+\kappa \pi_{1}+\left(\tilde{g}-g_{1}\right)+b_{1} \\
& \tilde{K}+\frac{(1-z) \tilde{x}}{v z}+(1+\rho) b_{1}=\left(\tau_{2}+\frac{\tilde{x}}{v z}\right)+\kappa \pi_{2}+\left(\tilde{g}-g_{2}\right)
\end{aligned}
$$

where $\tilde{K} \equiv \tilde{g}+\tilde{x} / v$. Note $\left(x_{t}-\tilde{x}\right)^{2}=z^{2} v^{2}\left(\pi_{t}^{e}-\pi_{t}+\tau_{t}+\frac{\tilde{x}}{v z}\right)^{2}$ from equation (1'), $z$ $=1$ in the normal situation, and $0<z<1$ in default of payment.

We assume that, in each period, the monetary authority cannot commit the inflation rate announced at the beginning of each period before nominal wages are set. Under this situation, the policy authorities take inflation expectations as predetermined. Such situation is represented in Figure 5 as a game tree.

$* * * *$ Insert Figure 5 here $* * * *$

\subsection{Policy choice in the second period}

To solve for the two-period decision problem, we use the backward induction method. Thus, we begin with solving for the solution in the second period and then proceed to solve for the solution in the first period. It implies that such a policy is a time-consistent policy, which is analyzed in Lucas and Stokey (1983), Persson, Persson and Svensson (1987, 2005), Calvo and Guidotti (1990a, $1990 \mathrm{~b})$ and so on. In the second period, the fiscal authority chooses $\left\{\tau_{2}, g_{2}\right\}$ to minimize its loss function, subject to the budget constraint (8-2). Also the monetary authority chooses $\left\{\pi_{2}\right\}$ to minimize its loss function, taking as given the expected inflation rate $\left(\pi_{2}^{e}\right)$, without any regard for the budget constraint (8-2).

\subsubsection{The normal case}

If the government does not trigger a debt default in the second period, we obtain the following conditions from the first order conditions for the choice of $\left\{\pi_{2}\right.$, $\left.\tau_{2}, g_{2}\right\}$, taking policies decided by the other authority and inflation expectation and $b_{1}$ as given,

$$
v\left(\tilde{x}-x_{2}\right)=\alpha_{g s}\left(\tilde{g}-g_{2}\right)=\alpha_{\pi M} \pi_{2}
$$

Moreover, from the above conditions and the government budget constraint and the 
restriction generated by the rational expectations formation of the private sector $\left(\pi_{2}^{e}=\pi_{2}\right)$, the following relations are held

$$
\begin{aligned}
& \pi_{2}=\frac{1}{\mathrm{~N} \alpha_{\pi S}}\left[\tilde{K}+(1+\rho) b_{1}\right] \\
& \tau_{2}+\frac{\tilde{x}}{v}=\frac{1}{\mathrm{~N} v^{2}}\left[\tilde{K}+(1+\rho) b_{1}\right] \\
& \tilde{g}-g_{2}=\frac{1}{\mathrm{~N} \alpha_{g S}}\left[\tilde{K}+(1+\rho) b_{1}\right] \\
& \quad \text { where } \mathrm{N} \equiv \frac{\kappa}{\alpha_{\pi M}}+\frac{1}{v^{2}}+\frac{1}{\alpha_{g S}}
\end{aligned}
$$

Hence, the value of the loss function of the fiscal authority is

$$
\begin{aligned}
\mathrm{V}_{2}{ }^{\mathrm{F}} \equiv \frac{1}{2} \frac{\mathrm{N}_{\mathrm{F}}{ }^{*}}{\mathrm{~N}^{2}}\left\{\tilde{K}+(1+\rho) b_{1}\right\}^{2} \\
\text { where } \mathrm{N}_{\mathrm{F}}{ }^{*} \equiv \frac{\alpha_{\pi F}}{\alpha_{\pi M}{ }^{2}}+\frac{1}{v^{2}}+\frac{1}{\alpha_{g S}}
\end{aligned}
$$

\subsubsection{The case of default}

If the government does declare a debt default in the second period, the government may decrease its value of the loss function. Then, investors would not buy the government bond in the first period if they can predict the debt default in the second period. In this situation, the government cannot issue the bonds in the first period, and does not have any bonds to default in the second period. Therefore, the government cannot trigger a default in the second period.

\subsection{Policy choice in the first period}

In the first period, investors of the government bonds firstly expect whether the government trigger a debt default. ${ }^{6}$ If they believe the default occurs, they do not buy the bonds at all. This situation is confidence crisis. Under this situation, the government cannot newly issue bonds $\left(b_{1}\right)$. If investors expect the default does not occur, the government bonds are freely traded.

After that, the fiscal authority chooses $\left\{\tau_{1}, g_{1}, b_{1}\right\}$ to minimize its loss function, subject to the budget constraint (8-1). Also the monetary authority chooses $\left\{\pi_{1}\right\}$ to minimize its loss function, without any regard for the budget constraint (8-1).

\subsubsection{The normal case under no confidence crisis (Case $\mathrm{N}$ )}

\footnotetext{
${ }^{6}$ As we mentioned above, the government may default only in the first period, not in the second period.
} 
First, we consider a situation that confidence crisis does not occur. Under this situation, the government can newly issue an one-period bond $\left(b_{1}\right)$. The fiscal and monetary authorities minimize their loss functions in consideration of situation in the second period. Thus the authorities in the first period have the following loss functions,

$$
\mathrm{V}_{1}^{a N}=\frac{1}{2}\left[\alpha_{\pi a} \pi_{1}^{2}+\left(x_{1}-\tilde{x}\right)^{2}+\alpha_{g S}\left(g_{1}-\tilde{g}\right)^{2}\right]+\beta_{S} \mathrm{~V}_{2}{ }^{a}
$$

where $a=F, M . \quad \mathrm{V}_{2}{ }^{a}$ denotes the value of loss function in the second period. $\quad \mathrm{V}_{2}{ }^{\mathrm{F}}$ is defined as (11), and $\mathrm{V}_{2}{ }^{\mathrm{M}}$ is obtained by assigning (10) to (7).

The monetary authority minimizes (12) regardless of the government budget constraint, taking policies selected by the fiscal authority and inflation expectation and $b_{0}$ as given. From the first order condition for the choice of $\left\{\pi_{1}\right\}$, we obtain the following condition

$$
v\left(\tilde{x}-x_{1}\right)=\alpha_{\pi M} \pi_{1}
$$

The fiscal authority minimizes its loss function.

$$
v\left(\tilde{x}-x_{1}\right)=\alpha_{g S}\left(\tilde{g}-g_{1}\right)=\beta_{N}^{*}\left[\tilde{K}+(1+\rho) b_{1}\right]
$$

where $\beta_{N}{ }^{*} \equiv \beta_{S}(1+\rho) \mathrm{N}_{\mathrm{F}}{ }^{*} / \mathrm{N}$. From the above conditions $(13-1,2)$ and the government budget constraint, the following relations are held under the rational expectations formation of the private sector $\left(\pi_{1}^{e}=\pi_{1}\right)$

$$
\begin{aligned}
& \tau_{1}+\frac{\tilde{x}}{v}=\frac{1}{\mathrm{~N} v^{2}}\left[\tilde{K}+(1+\rho) b_{0}-b_{1}\right] \\
& \pi_{1}=\frac{1}{\mathrm{~N} \alpha_{\pi M}}\left[\tilde{K}+(1+\rho) b_{0}-b_{1}\right] \\
& \tilde{g}-g_{1}=\frac{1}{\mathrm{~N} \alpha_{g S}}\left[\tilde{K}+(1+\rho) b_{0}-b_{1}\right] \\
& b_{1}=\frac{\delta_{2}}{1+\rho}\left[(1+\rho) b_{0}+\tilde{K}-\beta_{N}^{*} \tilde{K}\right]
\end{aligned}
$$

where $\delta_{2} \equiv \frac{1+\rho}{1+\beta_{S}(1+\rho)^{2} \mathrm{~N}_{\mathrm{F}}{ }^{*} / \mathrm{N}}$

Therefore, we obtain the value of the loss function as follows

$$
\begin{aligned}
\mathrm{V}_{1}^{\mathrm{FN}} & \equiv \frac{1}{2} \frac{\mathrm{N}_{\mathrm{F}}^{*}}{\mathrm{~N}^{2}}\left[\tilde{K}+(1+\rho) b_{0}-b_{1}\right]^{2}+\frac{1}{2} \beta_{S} \frac{\mathrm{N}_{\mathrm{F}}^{*}}{\mathrm{~N}^{2}}\left\{\tilde{K}+(1+\rho) b_{1}\right\}^{2} \\
& =\frac{1}{2} \frac{\mathrm{N}_{\mathrm{F}}^{*}}{\mathrm{~N}^{2}} \delta_{2}^{2}\left\{\left(\beta_{N}^{*}\right)^{2}+\beta_{S}\right\}\left[\tilde{K}+\frac{1}{1+\rho} \tilde{K}+(1+\rho) b_{0}\right]^{2}
\end{aligned}
$$

\subsubsection{The case of default under confidence crisis (Case D)}

Next, we consider a situation that confidence crisis occurs. Under this situation, the government cannot newly issue any bond $\left(b_{1}=0\right)$, and trigger a debt 
default in the first period.

The fiscal and monetary authorities minimize their loss functions. If once the government defaults on payments in the first period, however, the government has no debt in the second period, that is, there is no default in the second period. Thus the authorities in the first period have the following loss functions,

$$
\begin{aligned}
\mathrm{V}_{1}{ }^{a D}= & \frac{1}{2}\left[\alpha_{\pi a} \pi_{1}^{2}+\left(x_{1}-\tilde{x}\right)^{2}+\alpha_{g S}\left(g_{1}-\tilde{g}\right)^{2}\right]+\left.\beta_{S} V_{2}^{a}\right|_{b_{1}=0} \\
& \text { where } a=F, M \text {, and }\left.V_{2}^{a}\right|_{b_{1}=0}: \mathrm{V}_{2}{ }^{a} \text { with } b_{1}=0 .
\end{aligned}
$$

Also the production in this situation is determined by (1'). The government budget constraint in the first period becomes as follows,

$$
\tilde{K}+\frac{(1-z) \tilde{x}}{v z}=\left(\tau_{1}+\frac{\tilde{x}}{v z}\right)+\kappa \pi_{1}+\left(\tilde{g}-g_{1}\right) \quad 0<z<1
$$

The monetary authority minimizes (12') regardless of the government budget constraint, taking policies selected by the fiscal authority and inflation expectation as given. From the first order condition for the choice of $\left\{\pi_{1}\right\}$, we obtain the following condition

$$
v z\left(\tilde{x}-x_{1}\right)=\alpha_{\pi M} \pi_{1}
$$

The fiscal authority minimizes its loss function (12'), subject to (8-2). The authority sets policies to satisfy the following condition:

$$
v z\left(\tilde{x}-x_{1}\right)=\alpha_{g} s\left(\tilde{g}-g_{1}\right)
$$

From the above conditions (1'), (16-1, 2), and the government budget constraint (8-1'), the following relations are held under the rational expectations formation of the private sector $\left(\pi_{1}^{e}=\pi_{1}\right)$

$$
\begin{aligned}
& \pi_{1}=\frac{1}{\mathrm{H} \alpha_{\pi S}}\left[\tilde{K}+\frac{(1-z) \tilde{x}}{v z}\right] \\
& \tau_{1}+\frac{\tilde{x}}{v z}=\frac{1}{\mathrm{H} v^{2} z^{2}}\left[\tilde{K}+\frac{(1-z) \tilde{x}}{v z}\right] \\
& \tilde{g}-g_{1}=\frac{1}{\mathrm{H} \alpha_{g S}}\left[\tilde{K}+\frac{(1-z) \tilde{x}}{v z}\right] \\
& \text { where } \mathrm{H} \equiv \frac{\kappa}{\alpha_{\pi M}}+\frac{1}{v^{2} z^{2}}+\frac{1}{\alpha_{g S}}
\end{aligned}
$$

Therefore, we obtain the value of the loss function in this case as follows

$$
\begin{aligned}
\mathrm{V}_{1}{ }^{\mathrm{FD}} \equiv & \frac{1}{2} \frac{\mathrm{H}_{\mathrm{F}}^{*}}{\mathrm{H}^{2}}\left[\tilde{K}+\frac{(1-z) \tilde{x}}{v z}\right]^{2}+\frac{1}{2} \beta_{S} \frac{\mathrm{N}_{\mathrm{F}}{ }^{*}}{\mathrm{~N}^{2}} \tilde{K}^{2} \\
& \text { where } \mathrm{H}_{\mathrm{F}}{ }^{*} \equiv \frac{\alpha_{\pi F}}{\alpha_{\pi M}{ }^{2}}+\frac{1}{v^{2} z^{2}}+\frac{1}{\alpha_{g S}}
\end{aligned}
$$




\subsubsection{Welfare comparison between Case $\mathrm{N}$ and Case $\mathrm{D}$}

Whether the confidence crisis occurs or not in the first period depends on welfare loss of the fiscal authority in each case. If the government defaults on payments, investors of the government bonds face losses. Thus, they do not buy the bonds at all when they expect that the government trigger a debt default in the first period.

If $\mathrm{V}_{1}{ }^{\mathrm{FN}} \leq \mathrm{V}_{1}{ }^{\mathrm{FD}}$, the fiscal authority does not have any incentives to default in the first period. Hence, investors can purchase the government bonds. We further analyze this situation.

$$
\begin{aligned}
& \mathrm{V}_{1}{ }^{\mathrm{FN}} \leq \mathrm{V}_{1}{ }^{\mathrm{FD}} \text { is satisfied under the following conditions } \\
& 0 \leq b_{0} \leq-\frac{2+\rho}{(1+\rho)^{2}} \tilde{K}+\frac{1}{(1+\rho) \delta_{2}} \sqrt{\frac{\frac{H_{F}^{*} N^{2}}{N_{F}^{*} H^{2}}\left\{\tilde{K}+\frac{(1-z) \tilde{x}}{v z}\right\}^{2}+\beta_{S} \tilde{K}^{2}}{\left(\beta_{N}^{*}\right)^{2}+\beta_{S}}}
\end{aligned}
$$

When $\mathrm{V}_{1}{ }^{\mathrm{FN}} \leq \mathrm{V}_{1}{ }^{\mathrm{FD}}$, that is, condition (19) is held, investors buy the government bonds in the first period. It means that there is no confidence crisis in the first period under this situation. Otherwise, investors do not buy bonds at all in the first period. Thus confidence crisis occurs in the first period.

\subsection{Numerical Analysis}

In this subsection, we also numerically examine the above situation, which is theoretically analyzed in the previous subsection. We can easily extend the analytical framework to a more general T-period model. We will describe the detail setting of this numerical analysis in Appendix at the end of this paper.

In this numerical analysis we introduce the maturity structure of the government bonds to make it more realistic. We adopt this structure in fiscal 2003 (settlement basis) in Japan. The maturity structure of the outstanding debt is assumed to be given in Table 2. These ratios mean composition ratios to total amount of debt by remaining years to maturity. For example, the ratio of the government bonds which has the remaining year to maturity less than 1 year is about $36 \%$.

**** Insert Table 2 here $* * * *$

We also calculate the transition of policy variables in the realistic case described the above sections. As we mentioned, in the realistic case, the government may trigger a debt default. Thus can the fiscal authority avoid a default? Or does the authority have an incentive to default? We consider 
whether the government defaults on payment under our calibration setting.

We set the value of parameters used in this model as the same in the second best case in Section 3.4. Also we set $z=0.9$.

In the numerical analysis, we calculate the value of loss function of the fiscal authority in case of default $\left(\mathrm{V}_{\mathrm{t}}^{\mathrm{FD}}\right)$ and the value of loss function in case of no-default $\left(\mathrm{V}_{\mathrm{t}}^{\mathrm{FN}}\right)$ in each period, and then compare both values. If $\mathrm{V}_{\mathrm{t}}^{\mathrm{FD}} \geq \mathrm{V}_{\mathrm{t}}^{\mathrm{FN}}$, the government in period $t$ does not default. If $\mathrm{V}_{\mathrm{t}}^{\mathrm{FN}}>\mathrm{V}_{\mathrm{t}}^{\mathrm{FD}}$, the government triggers a default.

In conclusion, under our setting in the 200-period model, we find that the fiscal authority could still avoid a default, fortunately. First, the upper figure of Figure 6 shows the transition of outstanding debts. In this case, the fiscal authority takes such a policy that the outstanding of government bond increases first and it decreases sharply in the near the last period. This phenomenon seems to reflect the fact that the fiscal authority issues government bonds strategically. And it suggests that the outstanding debt in this situation does not exceed about $120 \%$. It is consistent with no default.

The lower figure of Figure 6 shows inflation rate $(\pi)$, government expenditure (to the desirable output ratio: $g$ ), and tax rate $(\tau)$. When the outstanding of government bonds is large, the issuance of new bonds results in the debt default. Therefore, the large amount of outstanding debt limits the fiscal authority to issue a new government bonds. As a result, issuance of government bonds leads the fiscal authority to an advantageous position against the monetary authority. In other words, the issuance of bonds works as a credible threat to the monetary authority. This mechanism leads the inflation rate to be higher, comparing to the second best case. Inflation rate becomes over $6 \%$. In contrast, the tax rate is kept low about $3 \%$.

$* * * *$ Insert Figure 6 here $* * * *$

\subsection{Intuitions of the analysis and policy implications}

According to conditions (19), the fiscal authority has an incentive to default when the amount of debt outstanding is more than a certain level. Expecting the debt default, the investors do not buy the public bonds at all. The public bonds, therefore, cannot be sold when the issuance leads the amount of debt outstanding to be more than the certain level. In this respect, the fiscal authority has to take into account the upper limit of stocks of public debt.

This possibility of debt default provides the fiscal authority to issue public 
bonds strategically in the first period. Suppose that fiscal authority, in the first period, issues public bonds to be paid in subsequent periods in a multi-period setting. The amount of issuance is, in addition, supposed to set to the extent that fiscal authority has to raise tax rate to finance the government spending and/or cut the government spending itself in the second period because the additional debt issuance is limited due to the possibility of the default in subsequent periods.

This strategic behavior of fiscal authority induces the monetary authority, in a later period, to boost output and raise seigniorage revenues to eliminate the distortion of resource allocation due to the limitation on debt issuance. Therefore, the monetary policy in a later period suffers from an inflation bias from the ax ante point of view. Expecting such future monetary policy, the fiscal authority has an incentive to issue more public bonds strategically in an earlier period because it will lead the fiscal authority to the advantageous position in the game played in a later period. This strategic bias of the fiscal authority results in the distortion of the resource allocation. ${ }^{7}$

There are two ways to eliminate this distortion toward successful fiscal reconstruction. One of them is to make the monetary authority more conservative than society in the sense that the price stability weight of monetary authority is higher than that of society. If the monetary authority is conservative enough not to raise inflation depending passively on the strategic accumulation of public bonds, the fiscal authority does not engage in the strategic accumulation of debt in an earlier period. Consequently the central bank should be more conservative to eliminate the distortion due to the strategic behavior of fiscal authority.

The other way of eliminating the distortion of the resource allocation is to design an institutional ceiling on the debt issuance. This institutional framework eliminates directly the distortion stemmed from the strategic behavior of the fiscal authority. Needless to say, this direct ceiling does not work effectively if the fiscal authority has not issued public bonds to the extent that the amount of debt outstanding is close to the critical level of debt default. It is therefore natural that the direct ceiling might not be necessary for many countries, but it can provide a binding constraint of the public bond issuance for the fiscal authority of Japan because it has accumulated the debt outstanding much more than other countries. ${ }^{8}$

\footnotetext{
${ }^{7}$ Since this strategic issuance of government bonds distorts the resource allocation form the ex ante point of view, it is considered to be one of the time inconsistency problems.

${ }^{8}$ One of the reasons why Japan has accumulated the debt drastically is related to the political situation of Japan in the 1990s. Especially after 1993, several parties formed a coalition government. This instability of government party in the Diet resulted in the delay of fiscal structural reform toward fiscal reconstruction because the politicians have to take into account
} 


\section{Conclusion}

If the expansionary trend in Japan's government spending continues at this pace, the fiscal deficit will inflate further and the ability to raise taxes in the future will be politically limited. Investors will lose confidence in Japan's public bonds if they believe that the nation's public finance is bound for long-term crisis. The result is that interest rates will rise and fiscal failure will become a more tangible reality.

This paper has analyzed sustainability issues of Japan's fiscal policy and then discussed the debt management policy using theoretical models and numerical studies. We also investigated the desirable coordination of fiscal and monetary authorities toward fiscal reconstruction.

We have also investigated confidence crisis of government debt and spontaneous default of fiscal authority. The fiscal authority has an incentive to default when the amount of debt outstanding is more than a certain level. Expecting the debt default, the investors do not buy the public bonds at all. The public bonds, therefore, cannot be sold when the issuance leads the amount of debt outstanding to be more than the certain level. In this respect, the fiscal authority has to take into account the upper limit of stocks of public debt. Our numerical study suggests that the fiscal authority could still avoid a default in Japan.

We have also showed that for a country with large stocks of public debt like Japan, the fiscal authority has an incentive to issue public bonds strategically. This strategic bias distorts the monetary authority to increase inflation too much. To eliminate this distortion bias and to attain fiscal reconstruction, an institutional ceiling on the debt issuance is one of the effective policy tools.

\section{Reference}

Alesina, A., A. Prati, and G. Tabellini, 1990, Public confidence and debt management: A model and a case study of Italy, in M. Draghi and R. Dornbusch, eds.. Public Debt Management: Theory and History, pp.94-124, Cambridge University Press.

Barro, R.J., 1979, On the determination of the public debt, Journal of Political Economy vol.87, pp.940-971.

Barro, R.J., 1995, Optimal debt management, NBER Working Paper No. 5327.

Barro, R.J., 2003, Optimal management of indexed and nominal debt, Annals of 
Economics and Finance vol.4, pp.1-15.

Beetsma, R.M.W.J. and A.L. Bovenberg, 1997a, Central bank independence and public debt policy, Journal of Economic Dynamics and Control vol.21, pp.873-894.

Beetsma, R.M.W.J. and A.L. Bovenberg, 1997b, Designing fiscal and monetary institutions in a second-best world, European Journal of Political Economy vol.13, pp.53-79.

Bertola, G. and A. Drazen, 1993, Trigger points and budget cuts: explaining the effect of fiscal austerity, American Economic Review vol.83, pp.11-26.

Blanchard, O.J. and P. Weil, 2001, Dynamic efficiency, the riskless rate, and debt Ponzi games under uncertainty, Advances in Macroeconomics vol.1, pp.5-27.

Bohn, H., 1991, The sustainability of budget deficits with lump-sum and with income-based taxation, Journal of Money, Credit, and Banking vol.23, pp.580-604.

Bohn, H., 1998, The behavior of U.S. public debt and deficits, Quarterly Journal of Economics vol.113, pp.949-963.

Broda, C., and D. Weinstein, 2005, Happy news from the dismal science: Reassessing Japanese fiscal policy and sustainability, in Takatoshi Ito, Hugh Patrick and David E. Weinstein eds., Reviving Japan's Economy, pp.40-78, The MIT Press.

Buiter, W.H. and K.M. Kletzer, 1992, Government solvency, Ponzi finance and the redundancy and usefulness of public debt, NBER Working Paper No.4076.

Bulow, J. and K. Rogoff, 1989, Sovereign debt: is to forgive to forget?, American Economic Review vol.79, pp.43-50.

Burbidge, J.B., 1983, Social security and savings plans in overlapping generations models, Journal of Public Economics vol.21, pp.79-92.

Calvo, G.A., 1988, Serving the public debt: the role of expectations, American Economic Review vol.78, pp.647-661.

Calvo, G.A. and P.E. Guidotti, 1990a, Credibility and nominal debt, IMF Staff Papers vol.37, pp.612-635.

Calvo, G.A. and P.E. Guidotti, 1990b, Indexation and maturity of government bonds: An exploratory model, in M. Draghi and R. Dornbusch eds., Public Debt Management: Theory and History, pp.52-82, Cambridge University Press.

Cargill, T., and N. Yoshino. 2000. The Postal Savings System, Fiscal Investment and Loan Program, and modernization of Japan's financial system, in Takeo Hoshi and Hugh Patrick, eds., Crisis and Change in the Japanese Financial System, pp.201-230, Kluwer Academic Publishers.

Cargill, T., and N. Yoshino, 2003, Postal Savings and Fiscal Investment in Japan, 
Oxford University Press.

Chari, V.V. and P.J. Kehoe, 1993, Sustainable plans and mutual default, Review of Economic Studies vol.60, pp.175-195.

Doi, T. and T. Hoshi, 2003, Paying for the FILP, in Magnus Blomström, Jennifer Corbett, Fumio Hayashi and Anil Kashyap eds., Structural Impediments to Growth in Japan, pp.37-69, University of Chicago Press.

Doi, T. and T. Ihori, 2002, Fiscal reconstruction and local interest groups in Japan, Journal of the Japanese and International Economies vol.16, no.4, pp.492-511.

Doi, T. and T. Ihori, 2003, Sustainability of Government Deficits in Japan: Including Trends in Local Government Finance, mimeo.

Drudi, F. and R. Giordano, 2000, Default risk and optimal debt management, Journal of Banking and Finance vol.24, pp.861-891.

Fujiki, H., H. Osano, and H. Uchida, 1998, Optimal contracts for central banker and public debt policy, Institute of Economic Research, Kyoto University Discussion Paper No.478.

Gale, D., 1973, Pure exchange equilibrium of dynamic economic models, Journal of Economic Theory vol.6, pp.12-36.

Giavazzi, F, and M. Pagano, 1990, Confidence crises and public debt management, in M. Draghi and R. Dornbusch, eds.. Public Debt Management: Theory and History, pp.125-143, Cambridge University Press.

Hamilton, J. and M. Flavin, 1986, On the limitations of government borrowing: A framework for empirical testing, American Economic Review vol.76, pp.808-816.

Ihori, T., 1988, Debt burden and intergeneration equity, in K.J. Arrow and M.J. Boskin eds., The Economics of Public Debt: Proceedings of a Conference held by the International Economic Association at Stanford, Macmillan.

Ihori, T., T. Doi, and H. Kondo, 2001, Japanese fiscal reform: fiscal reconstruction and fiscal policy, Japan and the World Economy vol.13, pp.351-370.

Ihori, T., T. Nakazato, and M. Kawade, 2002, Japan's fiscal policies in the 1990s, The World Economy vol.26, pp.325-338.

Ihori, T. and M. Sato eds., 2002, Government Deficit and Fiscal Reform in Japan, Kluwer Academic Publishers.

Lucas, R.E. and N.L. Stokey, 1983, Optimal fiscal and monetary policy in an economy without capital, Journal of Monetary Economics vol.12, pp.55-94.

McCallum, B.T., 1984, Are bond financed deficits inflationary? A Ricardian analysis, Journal of Political Economy vol.92, pp.123-135.

Persson, M., T. Persson and L.E.O. Svensson, 1987, Time consistency of fiscal and monetary policy, Econometrica vol.55, pp.1419-1431. 
Persson, M., T. Persson and L.E.O. Svensson, 2005, Time consistency of fiscal and monetary policy: A solution, NBER Working Paper No. 11088.

Samuelson, P.A., 1958, An exact consumption-loan model of interest with or without the social contrivance of money, Journal of Political Economy vol.66, pp.467-482.

Tirole, J., 1985, Asset bubbles and overlapping generations, Econometrica vol.53, pp.1071-1100.

Weil, P., 1989, Overlapping families of infinitely-lived agents, Journal of Public Economics vol.38, pp.183-198. 


\section{Appendix Numerical analysis in a realistic case}

In Section 4.4, we also numerically examine a realistic case, which is theoretically analyzed in Sections 4.1-4.3. We can easily extend the analytical framework to a more general T-period model. Now we introduce maturity structure of the government bond. The government can issue (inflation-indexed) bonds, and choose their maturity. The pure expectation hypothesis of interest rates is assumed to be held. In such a situation, the fiscal authority faces the following budget constraint in period $\mathrm{t}$;

$$
g_{t}+\sum_{s=0}^{t-1}(1+\rho)^{t-s} b_{s, t}=\tau_{t}+\kappa \pi_{t}+\sum_{v=t+1}^{T} b_{t, v}
$$

or

$$
\tilde{K}+\frac{(1-z) \tilde{x}}{v z}+\sum_{s=0}^{t-1}(1+\rho)^{t-s} b_{s, t}=\left(\tau_{t}+\frac{\tilde{x}}{v z}\right)+\kappa \pi_{t}+\left(\tilde{g}-g_{t}\right)+\sum_{v=t+1}^{T} b_{t, v}
$$

where $B_{s t}$ denotes the amount of bonds issued in period s with a prescribed payout in period $\mathrm{t}$ and $b_{s t} \equiv \frac{B_{s t}}{\tilde{X}}$. Note $z=1$ in the normal situation, and $0<z<1$ in default of payment. The initial maturity structure of the government bond $\left\{B_{0 v} \mid v\right.$ $\geq 1$ \} is exogenously given for the government in each period. The government in period t chooses $g_{t}, \tau_{t}, b_{t v}(t+1 \leq v \leq T)$.

\section{A.1. The normal case in the final period}

If the government does not trigger a debt default in the final period (period $\mathrm{T}$ ), we obtain the following conditions from the first order conditions for the choice of $\left\{\pi_{T}, \tau_{T}, g_{T}\right\}$, taking policies decided by the other authority and inflation expectation as given,

$$
v\left(\tilde{x}-x_{T}\right)=\alpha_{g S}\left(\tilde{g}-g_{T}\right)=\alpha_{\pi M} \pi_{T}
$$

Moreover, from the above conditions and the government budget constraint and the restriction generated by the rational expectations formation of the private sector $\left(\pi_{T}^{e}=\pi_{T}\right)$, the following relations are held

$$
\begin{aligned}
& \pi_{T}=\frac{1}{\mathrm{~N} \alpha_{\pi S}}\left[\tilde{K}+b_{T}\right] \\
& \tau_{T}+\frac{\tilde{x}}{v}=\frac{1}{\mathrm{~N} v^{2}}\left[\tilde{K}+b_{T}\right] \\
& \tilde{g}-g_{T}=\frac{1}{\mathrm{~N} \alpha_{g S}}\left[\tilde{K}+b_{T}\right]
\end{aligned}
$$


where $b_{T} \equiv \sum_{s=0}^{T-1}(1+\rho)^{T-s} b_{s T}$. Hence, the value of the loss function of the fiscal authority is

$$
\mathrm{V}_{T}^{\mathrm{FN}} \equiv \frac{1}{2} \frac{\mathrm{N}_{\mathrm{F}}^{*}}{\mathrm{~N}^{2}}\left[\tilde{K}+b_{T}\right]^{2}
$$

\section{A.2. Policy choice in period $\mathrm{T}-1$}

In period $\mathrm{T}-1$, investors of the government bonds firstly expect whether the government trigger a debt default (in period $\mathrm{T}-1$ or the period $\mathrm{T}$ ). If they believe the default occurs, they do not buy the bonds at all. This situation is confidence crisis. Under this situation, the government cannot newly issue bonds $\left(b_{T-1, T}\right)$. If investors expect the default does not occur, the government bonds are freely treaded.

After that, the fiscal authority chooses $\left\{\tau_{T-1}, g_{T-1}, b_{T-1, T}\right\}$ to minimize its loss function, subject to the budget constraint (A-1). Also the monetary authority chooses $\left\{\pi_{T-1}\right\}$ to minimize its loss function, without any regard for the budget constraint (A-1).

\section{A.2.1. The normal case (Case $\mathbf{N})$}

First, we consider a situation that confidence crisis does not occur. Under this situation, the government can newly issue an one-period bond $\left(b_{T-1, T}\right)$. The fiscal and monetary authorities minimize their loss functions. Thus the authorities in period $\mathrm{T}-1$ have the following loss functions,

$$
\mathrm{V}_{T-1}{ }^{a}=\frac{1}{2}\left[\alpha_{\pi a} \pi_{T-1}^{2}+\left(x_{T-1}-\tilde{x}\right)^{2}+\alpha_{g S}\left(g_{T-1}-\tilde{g}\right)^{2}\right]+\beta_{S} \mathrm{~V}_{T}^{a \mathrm{~N}}
$$

where $a=F, M . \quad \mathrm{V}_{T}^{a \mathrm{~N}}$ denotes the value of loss function in the normal case in the final period. $\quad \mathrm{V}_{T}^{\mathrm{FN}}$ is defined as (A-3), and $\mathrm{V}_{T}^{\mathrm{MN}}$ is obtained by assigning (A-2) to (7).

The monetary authority minimizes (A-4) regardless of the government budget constraint, taking policies selected by the fiscal authority and inflation expectation as given. From the first order condition for the choice of $\left\{\pi_{T-1}\right\}$, we obtain the following condition

$$
v\left(\tilde{x}-x_{T-1}\right)=\alpha_{\pi M} \pi_{T-1}
$$

The fiscal authority minimizes its loss function and sets policies to satisfy the following conditions:

$$
v\left(\tilde{x}-x_{T-1}\right)=\alpha_{g S}\left(\tilde{g}-g_{T-1}\right)=\beta_{N}^{*}\left[\tilde{K}+b_{T}\right]
$$

From the above conditions (A-5-1, 2) and the government budget 
constraint, the following relations are held under the rational expectations formation of the private sector $\left(\pi_{T-1}^{e}=\pi_{T-1}\right)$

$$
\begin{aligned}
& b_{T-1, T}=\delta_{T-1}\left[\tilde{K}+b_{T-1}-\beta_{N}^{*}\left\{\tilde{K}+\sum_{s=0}^{T-2}(1+\rho)^{T-s} b_{s, T}\right]\right. \\
& \tau_{T-1}+\frac{\tilde{x}}{v}=\frac{1}{\mathrm{~N} v^{2}}\left[\tilde{K}+b_{T-1}-b_{T-1, T}\right] \\
& =\frac{1}{\mathrm{~N} v^{2}} \delta_{T-1} \beta_{N}^{*}\left[\tilde{K}+b_{T-1}+\frac{1}{1+\rho}\left\{\tilde{K}+(1+\rho)^{3} b_{03}+(1+\rho)^{2} b_{13}\right\}\right] \\
& \pi_{T-1}=\frac{1}{\mathrm{~N} \alpha_{\pi M}} \delta_{T-1} \beta_{N}^{*}\left[\tilde{K}+b_{T-1}+\frac{1}{1+\rho}\left\{\tilde{K}+(1+\rho)^{3} b_{03}+(1+\rho)^{2} b_{13}\right\}\right] \\
& \tilde{g}-g_{T-1}=\frac{1}{\mathrm{~N} \alpha_{g S}} \delta_{T-1} \beta_{N}{ }^{*}\left[\tilde{K}+b_{T-1}+\frac{1}{1+\rho}\left\{\tilde{K}+(1+\rho)^{3} b_{03}+(1+\rho)^{2} b_{13}\right\}\right]
\end{aligned}
$$

where $b_{T-1} \equiv \sum_{s=0}^{T-2}(1+\rho)^{T-1-s} b_{s, T-1}, \delta_{T-1} \equiv \frac{1+\rho}{1+\beta_{S}(1+\rho)^{2} \mathrm{~N}_{\mathrm{F}}{ }^{*} / \mathrm{N}}$. Therefore, we obtain the value of the loss function as follows

$$
\begin{aligned}
& \mathrm{V}_{T-1}{ }^{\mathrm{FN}} \equiv \frac{1}{2} \frac{\mathrm{N}_{\mathrm{F}}^{*}}{\mathrm{~N}^{2}}\left[\tilde{K}+b_{T-1}-b_{T-1, T}\right]^{2}+\frac{1}{2} \beta_{S} \frac{\mathrm{N}_{\mathrm{F}}{ }^{*}}{\mathrm{~N}^{2}}\left(\tilde{K}+b_{T}\right)^{2} \\
& =\frac{1}{2} \frac{\mathrm{N}_{\mathrm{F}}^{*}}{\mathrm{~N}^{2}} \delta_{T-1}{ }^{2}\left\{\left(\beta_{N}{ }^{*}\right)^{2}+\beta_{S}\right\}\left[\tilde{K}+b_{T-1}+\frac{1}{1+\rho}\left\{\tilde{K}+\sum_{s=0}^{T-2}(1+\rho)^{T-s} b_{s, T}\right\}\right]^{2}
\end{aligned}
$$

\section{A.2.2. The case of default in the final period under confidence crisis (Case C)}

Next, we consider a situation that confidence crisis occurs. Under this situation, the government cannot newly issue any bond $\left(b_{T-1, T}=0\right)$. The fiscal and monetary authorities minimize their loss functions in consideration of situation in the final period; whether the government faces a debt default or not in the final period.

At first, we consider the case that default occurs in the final period. When the government does declare a debt default in the final period, the government budget constraint in the final period becomes (A-1) with $z \neq 0$. Under this situation, we obtain the following conditions from the first order conditions for the choice of $\left\{\pi_{T}, \tau_{T}, g_{T}\right\}$, taking policies decided by the other authority and inflation expectation as given,

$$
v z\left(\tilde{x}-x_{T}\right)=\alpha_{g s}\left(\tilde{g}-g_{T}\right)=\alpha_{\pi M} \pi_{T}
$$

Moreover, from the above conditions (1') and (12), and the government budget constraint (A-8) and the restriction generated by the rational expectations formation of the private sector $\left(\pi_{T}^{e}=\pi_{T}\right)$, the following relations are held 


$$
\begin{aligned}
& \pi_{T}=\frac{1}{\mathrm{H} \alpha_{\pi s}}\left[\tilde{K}+\frac{(1-z) \tilde{x}}{v z}\right] \\
& \tau_{T}+\frac{\tilde{x}}{v z}=\frac{1}{\mathrm{H}^{2} z^{2}}\left[\tilde{K}+\frac{(1-z) \tilde{x}}{v z}\right] \\
& \tilde{g}-g_{T}=\frac{1}{\mathrm{H} \alpha_{g S}}\left[\tilde{K}+\frac{(1-z) \tilde{x}}{v z}\right]
\end{aligned}
$$

Hence, the value of the loss function of the fiscal authority is

$$
\mathrm{V}_{T}^{\mathrm{FD}} \equiv \frac{1}{2} \frac{\mathrm{H}_{\mathrm{F}}^{*}}{\mathrm{H}^{2}}\left[\tilde{K}+\frac{(1-z) \tilde{x}}{v z}\right]^{2}
$$

Next we investigate policy choice in period $\mathrm{T}-1$. The authorities in period $\mathrm{T}-1$ are written as

$$
\mathrm{V}_{T-1}{ }^{a \mathrm{C}}=\frac{1}{2}\left[\alpha_{\pi a} \pi_{T-1}^{2}+\left(x_{T-1}-\tilde{x}\right)^{2}+\alpha_{g S}\left(g_{T-1}-\tilde{g}\right)^{2}\right]+\beta_{S} \mathrm{~V}_{T-1}{ }^{a \mathrm{D}}
$$

where $a=F, M$. The monetary authority minimizes (A-11) regardless of the government budget constraint, taking policies selected by the fiscal authority and inflation expectation as given. Since this situation is the same as Case $C$, condition with respect to $\left\{\pi_{T-1}\right\}$ in this case is (A-5-1).

The fiscal authority minimizes its loss functions in consideration of situation in the final period. The government decides policies to satisfy the condition,

$$
v\left(\tilde{x}-x_{T-1}\right)=\alpha_{g S}\left(\tilde{g}-g_{T-1}\right)
$$

Therefore, we obtain the value of the loss function in this case as follows

$$
\mathrm{V}_{T-1}{ }^{\mathrm{FC}} \equiv \frac{1}{2} \frac{\mathrm{N}_{\mathrm{F}}^{*}}{\mathrm{~N}^{2}}\left[\tilde{K}+b_{T-1}\right]^{2}+\frac{1}{2} \beta_{S} \frac{\mathrm{H}_{\mathrm{F}}^{*}}{\mathrm{H}^{2}}\left[\tilde{K}+\frac{(1-z) \tilde{x}}{v z}\right]^{2}
$$

\section{A.2.3. The case of default in period $T-1$ under confidence crisis (Case $D$ )}

Also, we discuss the situation that the government in period $\mathrm{T}-1$ triggers a debt default under confidence crisis. Under this situation, the government cannot newly issue an one-period bond $\left(b_{T-1, T}=0\right)$.

The fiscal and monetary authorities minimize their loss functions in consideration of situation in the final period. If once the government defaults on payments in period $\mathrm{T}-1$, however, the government has no debt in the final period, that is, there is no default in the final period. Thus the authorities in period $\mathrm{T}-1$ have the following loss functions,

$$
\mathrm{V}_{T-1}^{a}=\frac{1}{2}\left[\alpha_{\pi a} \pi_{T-1}^{2}+\left(x_{T-1}-\tilde{x}\right)^{2}+\alpha_{g S}\left(g_{T-1}-\tilde{g}\right)^{2}\right]+\beta_{S} V_{T}^{a N} \mathrm{I}_{b_{T}=0}
$$

where $a=F, M$. The government budget constraint in this period is (A-1) with $z \neq$ 1 . 
The monetary authority minimizes (A-13) regardless of the government budget constraint, taking policies selected by the fiscal authority and inflation expectation as given. From the first order condition for the choice of $\left\{\pi_{T-1}\right\}$, we obtain the following condition

$$
v z\left(\tilde{x}-x_{T-1}\right)=\alpha_{\pi M} \pi_{T-1}
$$

The fiscal authority minimizes its loss function (A-13), subject to (A-1). The authority sets policies to satisfy the following condition:

$$
v z\left(\tilde{x}-x_{T-1}\right)=\alpha_{g s}\left(\tilde{g}-g_{T-1}\right)
$$

From the above conditions (1'), (A-14-1, 2), and the government budget constraint (A-1), the following relations are held under the rational expectations formation of the private sector $\left(\pi_{T-1}^{e}=\pi_{T-1}\right)$

$$
\begin{aligned}
& \pi_{T-1}=\frac{1}{\mathrm{H} \alpha_{\pi S}}\left[\tilde{K}+\frac{(1-z) \tilde{x}}{v z}\right] \\
& \tau_{T-1}+\frac{\tilde{x}}{v z}=\frac{1}{\mathrm{H} v^{2} z^{2}}\left[\tilde{K}+\frac{(1-z) \tilde{x}}{v z}\right] \\
& \tilde{g}-g_{T-1}=\frac{1}{\mathrm{H} \alpha_{g S}}\left[\tilde{K}+\frac{(1-z) \tilde{x}}{v z}\right]
\end{aligned}
$$

Therefore, we obtain the value of the loss function in this case as follows

$$
\mathrm{V}_{T-1}{ }^{\mathrm{FD}} \equiv \frac{1}{2} \frac{\mathrm{H}_{\mathrm{F}}^{*}}{\mathrm{H}^{2}}\left[\tilde{K}+\frac{(1-z) \tilde{x}}{v z}\right]^{2}+\frac{1}{2} \beta_{S} \frac{\mathrm{N}_{\mathrm{F}}^{*}}{\mathrm{~N}^{2}} \tilde{K}^{2}
$$

\section{A.2.4. Welfare comparison between Case C and Case D}

Dose the fiscal authority trigger a debt default under no confidence crisis? It depends on the value of the loss function of the fiscal authority in each case.

If $\mathrm{V}_{T-1}{ }^{\mathrm{FD}} \geq \mathrm{V}_{T-1}{ }^{\mathrm{FC}}$, the government does not trigger a default in period $\mathrm{T}-1$. On the other hand, in the case of $\mathrm{V}_{2}{ }^{\mathrm{FD}}<\mathrm{V}_{2}{ }^{\mathrm{FC}}$, the fiscal authority has incentives to default on payments in period $\mathrm{T}-1$.

The details are as follows. In the case of $\tilde{K}>\frac{N \tilde{x} v z}{1+z}$ and $D>\tilde{K}^{2}, \mathrm{~V}_{T-1}{ }^{\mathrm{FD}}$ $>\mathrm{V}_{T-1}{ }^{\mathrm{FC}}$ is satisfied under the following conditions

$$
b_{T-1}>\sqrt{\beta_{S} \tilde{K}^{2}+\left(1-\beta_{S}\right) D}-\tilde{K},
$$

These conditions suggest that the government has an incentive to default when the amount of debt outstanding is more than a certain level.

\section{A.2.5. Welfare comparison between Case $\mathbf{N}$ and Case $\mathbf{C}$ or Case $\mathbf{D}$}

Whether the confidence crisis occurs or not in period $\mathrm{T}-1$ depends on 
welfare loss of the fiscal authority in each case. If the government defaults on payments, investors of the government bonds face losses. Thus, they do not buy the bonds at all when they expect that the government trigger a debt default in period $\mathrm{T}-1$ or the final period.

If $\mathrm{V}_{T-1}{ }^{\mathrm{FN}} \leq \min \left\{\mathrm{V}_{T-1}{ }^{\mathrm{FC}}, \mathrm{V}_{T-1}{ }^{\mathrm{FD}}\right\}$, the fiscal authority does not have any incentives to default in each period. Hence, investors can purchase the government bonds. We further analyze this situation.

$$
\begin{aligned}
& \mathrm{V}_{T-1}{ }^{\mathrm{FN}}<\mathrm{V}_{T-1}{ }^{\mathrm{FC}}<\mathrm{V}_{T-1}{ }^{\mathrm{FD}} \text { is satisfied, under the following conditions } \\
& 0<b_{\mathrm{N}, T-1}<\beta_{S} D-\tilde{K}^{2}\left\{\gamma_{T-1}\left(1+\frac{1}{1+\rho}\right)^{2}-1\right\}
\end{aligned}
$$

where $\gamma_{T-1} \equiv \delta_{T-1}^{2}\left\{\left(\beta_{N}\right)^{2}+\beta_{S}\right\}, b_{\mathrm{N}, T-1} \equiv\left(\gamma_{T-1}-1\right) b_{T-1}^{2}+\gamma_{T-1}\left\{\sum_{s=0}^{T-2}(1+\rho)^{T-s} b_{s, T}\right\}^{2}+$ $2 \gamma_{T-1} b_{T-1} \sum_{s=0}^{T-2}(1+\rho)^{T-s} b_{s, T}-2 \tilde{K} b_{T-1}+2 \tilde{K} \gamma_{T-1}\left(1+\frac{1}{1+\rho}\right)\left[b_{T-1}+\sum_{s=0}^{T-2}(1+\rho)^{T-s} b_{s, T}\right]$,

$$
b_{T-1} \leq \sqrt{\beta_{S} \tilde{K}^{2}+\left(1-\beta_{S}\right) D}-\tilde{K},
$$

and

$$
\gamma_{T-1}<\frac{1+\beta_{S} D}{\left(1+\frac{1}{1+\rho}\right)^{2}}
$$

On the other hand, $\mathrm{V}_{T-1}{ }^{\mathrm{FN}}<\mathrm{V}_{T-1}{ }^{\mathrm{FD}}<\mathrm{V}_{T-1}{ }^{\mathrm{FC}}$ is satisfied under (A-17) and the following conditions

$$
0<b_{T-1}+\sum_{s=0}^{T-2}(1+\rho)^{T-s} b_{s, T}<\sqrt{\frac{D+\beta \tilde{K}}{\gamma_{T-1}}}-\left(1+\frac{1}{1+\rho}\right) \tilde{K}
$$

and

$$
\gamma_{T-1}<\frac{D+\beta_{S} \tilde{K}^{2}}{\left(1+\frac{1}{1+\rho}\right)^{2} \tilde{K}^{2}}
$$

When $\mathrm{V}_{T-1}{ }^{\mathrm{FN}} \leq \min \left\{\mathrm{V}_{T-1}{ }^{\mathrm{FC}}, \mathrm{V}_{T-1}{ }^{\mathrm{FD}}\right\}$, that is, conditions (A-17') and (A-18) or (A-17) and (A-19) are held, investors buy the government bonds in period $\mathrm{T}-1$. It means that there is no confidence crisis in period $\mathrm{T}-1$ under this situation. Otherwise, investors do not buy bonds at all in period $\mathrm{T}-1$. Thus confidence crisis occurs in period $\mathrm{T}-1$. 


\section{A.3. Policy choice in period $t$}

In general, in period $t$, investors of the government bonds firstly expect whether the government trigger a debt default in subsequent periods. If they believe the default occurs, they do not buy the bonds at all. This situation is confidence crisis. Under this situation, the government cannot newly issue bonds. If investors expect the default does not occur, the government bonds are freely treaded.

After that, the fiscal authority chooses $\left\{\tau_{t}, g_{t}, b_{t s}\right\}$ to minimize its loss function, subject to the budget constraint (A-1). Also the monetary authority chooses $\left\{\pi_{t}\right\}$ to minimize its loss function, without any regard for the budget constraint (A-1). The structure of this policy game from period $\mathrm{T}-2$ to period $\mathrm{T}$, for example, is shown in Figure A.

$* * * *$ Insert Figure A here ****

\section{A.3.1. The normal case (Case $\mathbf{N})$}

First, we consider a situation that confidence crisis does not occur. Under this situation, the government can newly issue bonds. The fiscal and monetary authorities minimize their loss functions. Thus the authorities in period $\mathrm{T}-1$ have the following loss functions,

$$
\mathrm{V}_{t}^{a \mathrm{~N}}=\frac{1}{2}\left[\alpha_{\pi a} \pi_{t}^{2}+\left(x_{t}-\tilde{x}\right)^{2}+\alpha_{g S}\left(g_{t}-\tilde{g}\right)^{2}\right]+\beta_{S} \mathrm{~V}_{t+1}^{a \mathrm{~N}}
$$

where $a=F, M . \quad \mathrm{V}_{t+1}{ }^{a \mathrm{~N}}$ denotes the value of loss function in the normal case in the final period. From the first order conditions like (A-6), the value of the loss function of the fiscal authority in period $t$ in the normal case becomes

$$
V_{t}^{F N}=\frac{N_{F}^{*}}{2 N^{2}} \gamma_{t}\left[\tilde{K} \sum_{s=t}^{T}(1+\rho)^{t-s}+\sum_{s=0}^{t-1}\left\{(1+\rho)^{t-s} \sum_{v=t}^{T} b_{s, v}\right\}\right]^{2}
$$

where $\quad \gamma_{t} \equiv\left\{\left(\beta_{N}^{*} \gamma_{t+1}\right)^{2}+\beta_{s} \gamma_{t+1}\right\} \delta_{t}^{2}, \gamma_{T}=1, \delta_{t} \equiv \frac{1+\rho}{1+\gamma_{t+1}(1+\rho) \beta_{N}^{*}} \quad, \quad$ and the (optimizing) newly issued bond in period $\mathrm{t}$ is

$$
\sum_{v=t+1}^{T} b_{t, v}=\frac{\delta_{t}}{1+\rho}\left\{\tilde{K}+\sum_{s=0}^{t-1}(1+\rho)^{t-s} b_{s, t}-\gamma_{t+1} \beta_{N}^{*}\left[\tilde{K} \sum_{s=t+1}^{T}(1+\rho)^{t+1-s}+\sum_{s=0}^{t-1}\left\{(1+\rho)^{t+1-s} \sum_{v=t+1}^{T} b_{s, v}\right\}\right]\right\}
$$

\section{A.3.2. The case of default under confidence crisis}

Next, we consider a situation that confidence crisis occurs in period $t$. Under this situation, the government cannot newly issue any bond in this and 
subsequent periods. If the government triggers debt default in period $t$, we also obtain the value of the loss function of the fiscal authority in period $t$ in default case as follows

$$
V_{t, 0}^{F D} \equiv \frac{H_{F}^{*}}{2 H^{2}}\left[\tilde{K}+\frac{(1-z) \tilde{x}}{v z}\right]^{2}+\frac{N_{F}^{*}}{2 N^{2}} \gamma_{t+1}\left[\tilde{K} \sum_{s=t+1}^{T}(1+\rho)^{t+1-s}\right]^{2},
$$

from the first order conditions like (A-14-1, 2). Likewise, if the government defaults in period $\mathrm{t}+\mathrm{j}(0 \leq j \leq \mathrm{T}-\mathrm{t})$, from the first order conditions like (A-5-1), (A-5-2') and (A-9), the value of the loss function of the fiscal authority in period $t$ becomes

$$
\begin{aligned}
& V_{t, j}^{F D} \equiv \beta_{S}^{j} \frac{H_{F}^{*}}{2 H^{2}}\left[\tilde{K}+\frac{(1-z) \tilde{x}}{v z}\right]^{2} \\
&+\frac{N_{F}^{*}}{2 N^{2}}\left[\beta_{S}^{j+1} \gamma_{t+j+1}\left\{\tilde{K} \sum_{s=t+j+1}^{T}(1+\rho)^{t+j+1-s}\right\}^{2}+\sum_{h=t}^{t+j-1} \beta_{S}^{h-t}\left\{\tilde{K}+\sum_{v=0}^{t-1}(1+\rho)^{h-v} b_{v, h}\right\}^{2}\right]
\end{aligned}
$$

We define $\mathrm{V}_{t}^{\mathrm{FD}} \equiv \min \left\{\mathrm{V}_{t, j}{ }^{\mathrm{FD}} \mid 0 \leq j \leq \mathrm{T}-\mathrm{t}\right\}$.

Hence, if $\mathrm{V}_{t}^{\mathrm{FN}} \leq \mathrm{V}_{t}^{\mathrm{FD}}$, the fiscal authority does not have any incentives to default in period t. We numerically examine a realistic case based on the above setting in Section 4.4 . 
Figure 1

Primary Surplus and Government Debt

(The general account of the central government)

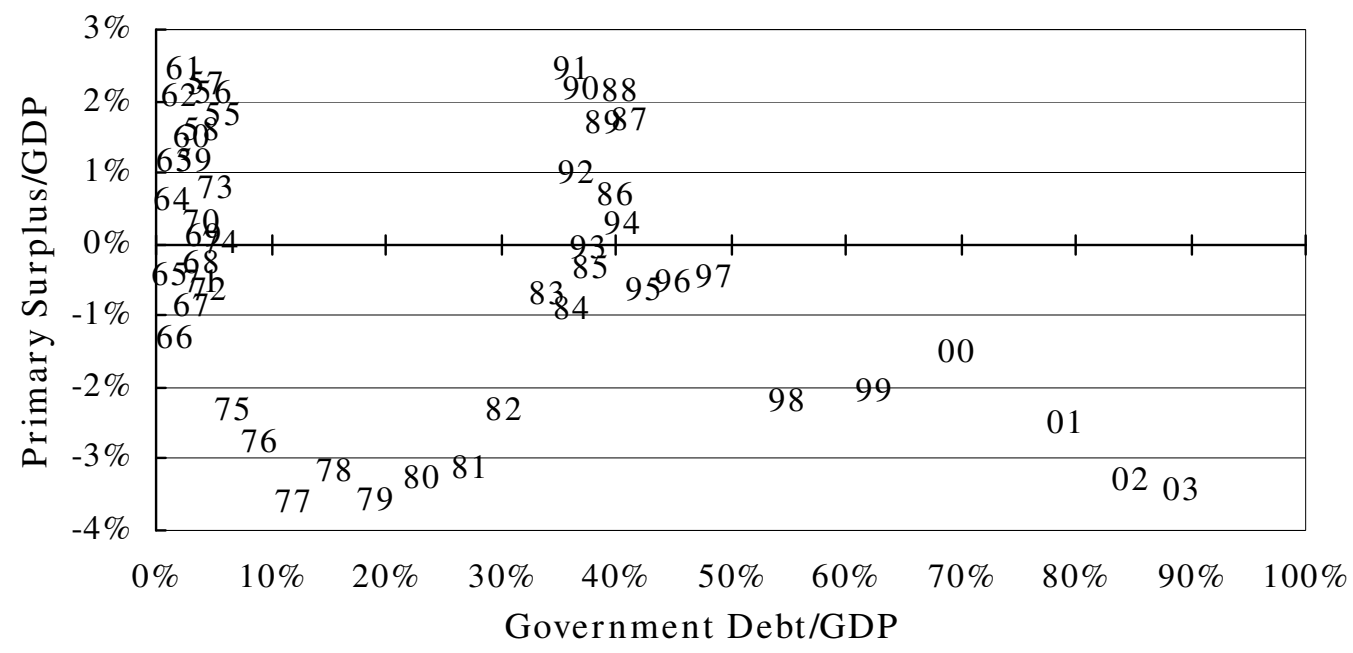


Figure 2

Primary Surplus and Government Debt

(Central and local governments)

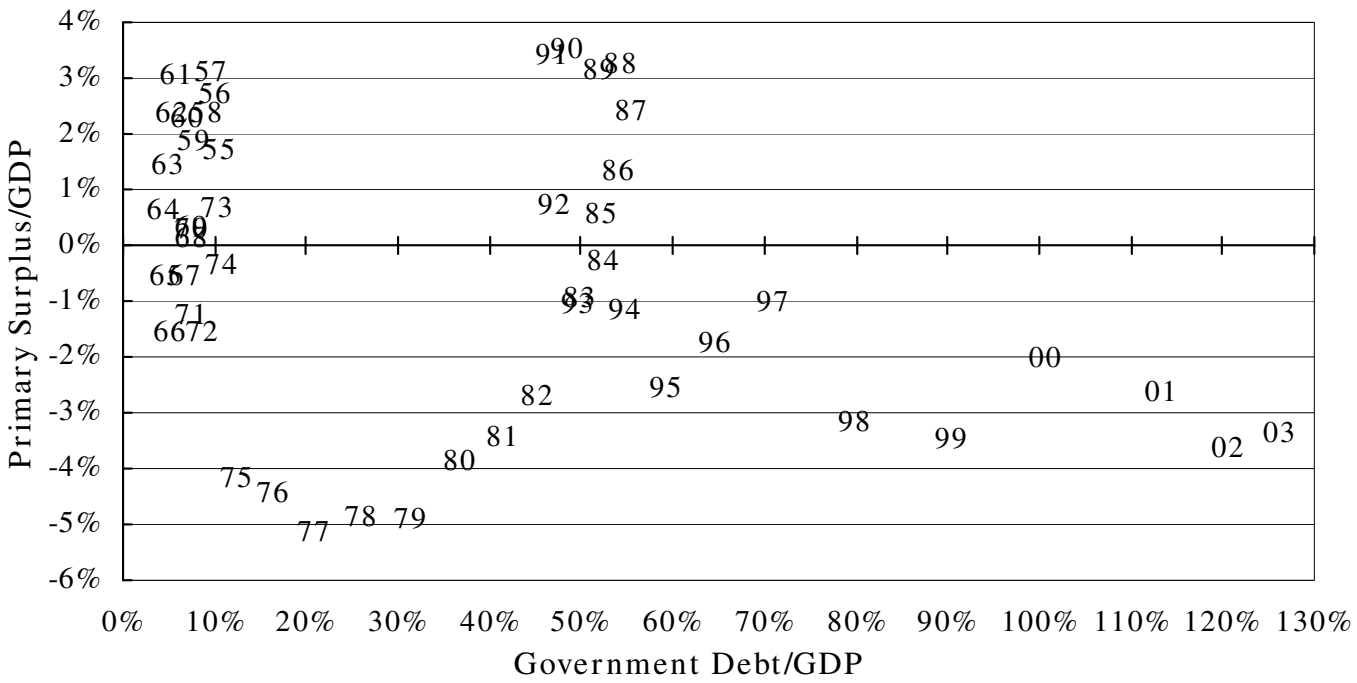


Figure 3

Maturity Structure of Government Bonds

(Outstanding Basis)

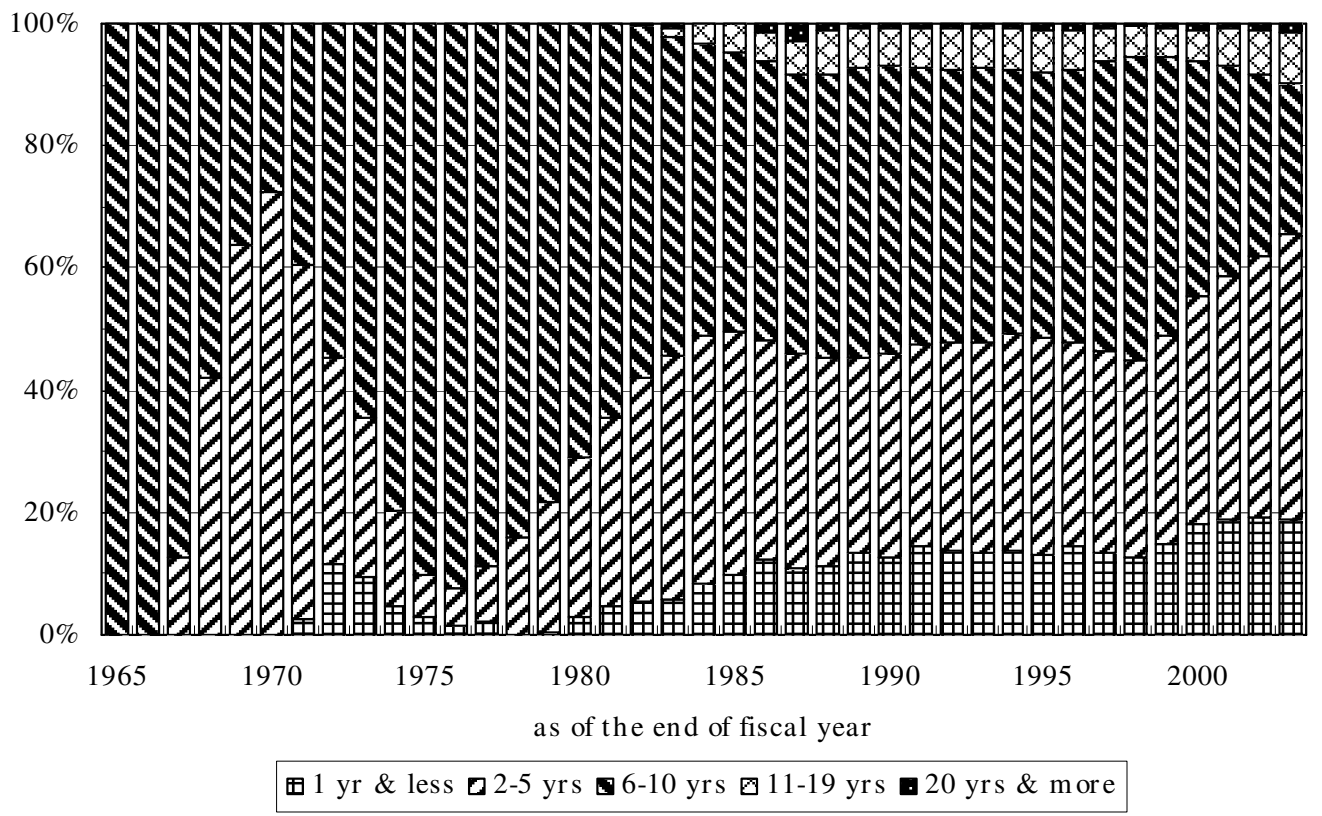


Figure 4

Result of Numerical Analysis in the Second Best Case

Bond to GDP ratio

Outstanding Bonds

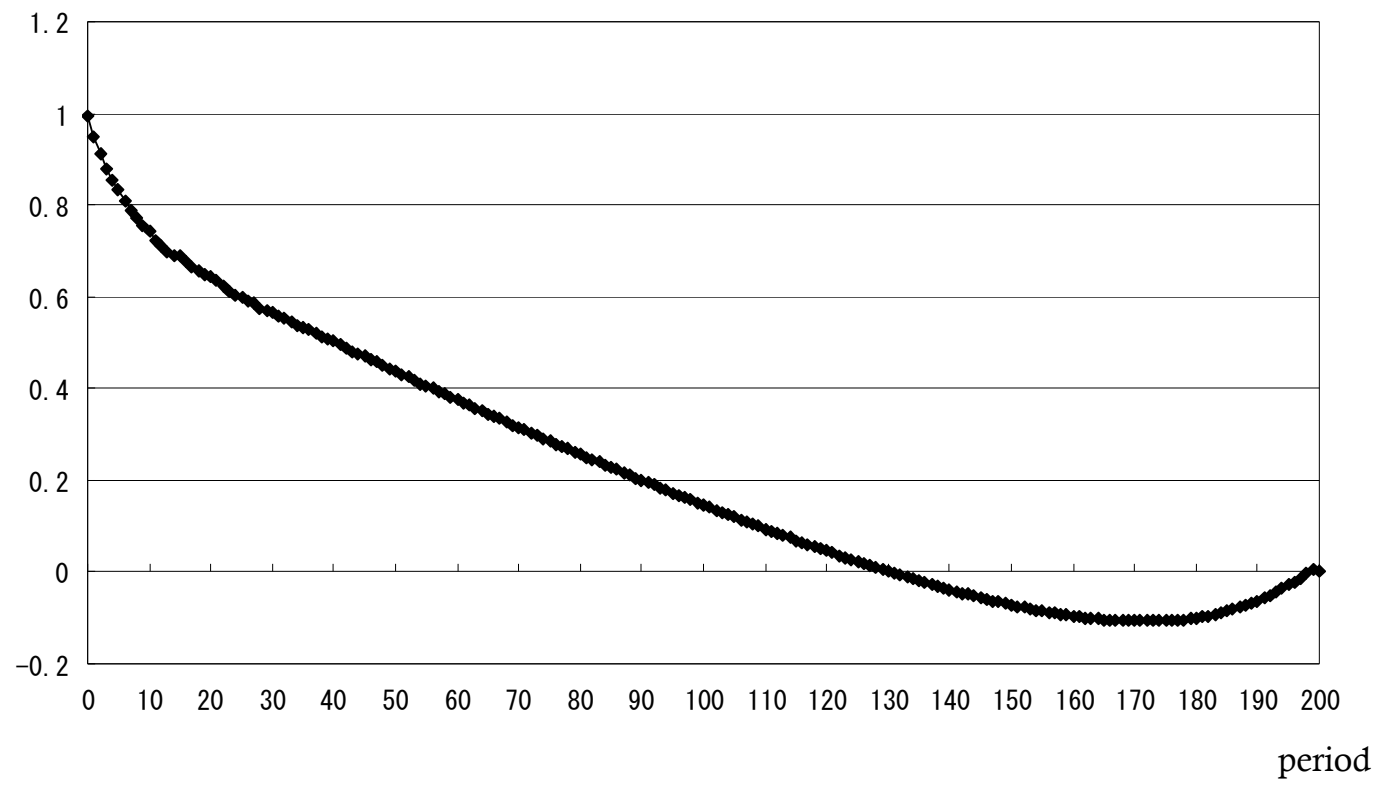

Tax rate, government spending and inflation rate

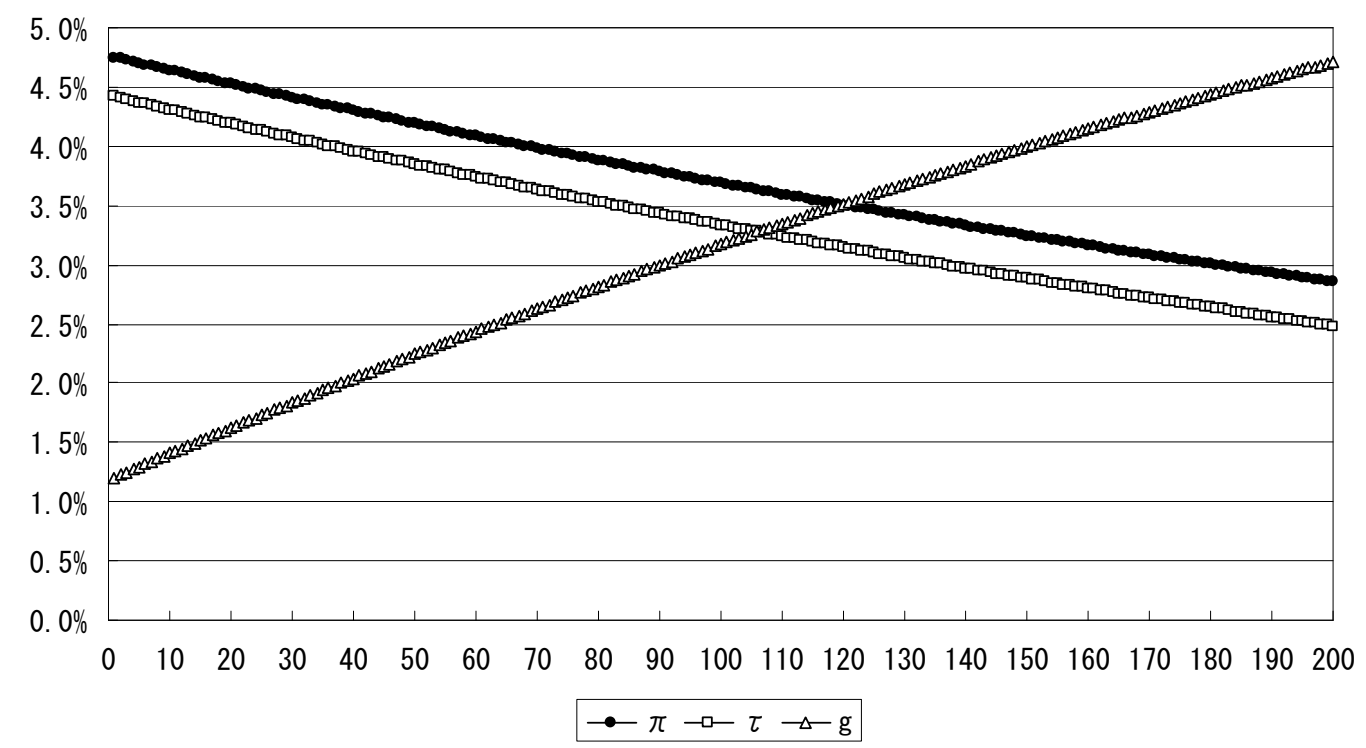

period 
Figure 5

The structure of the policy game

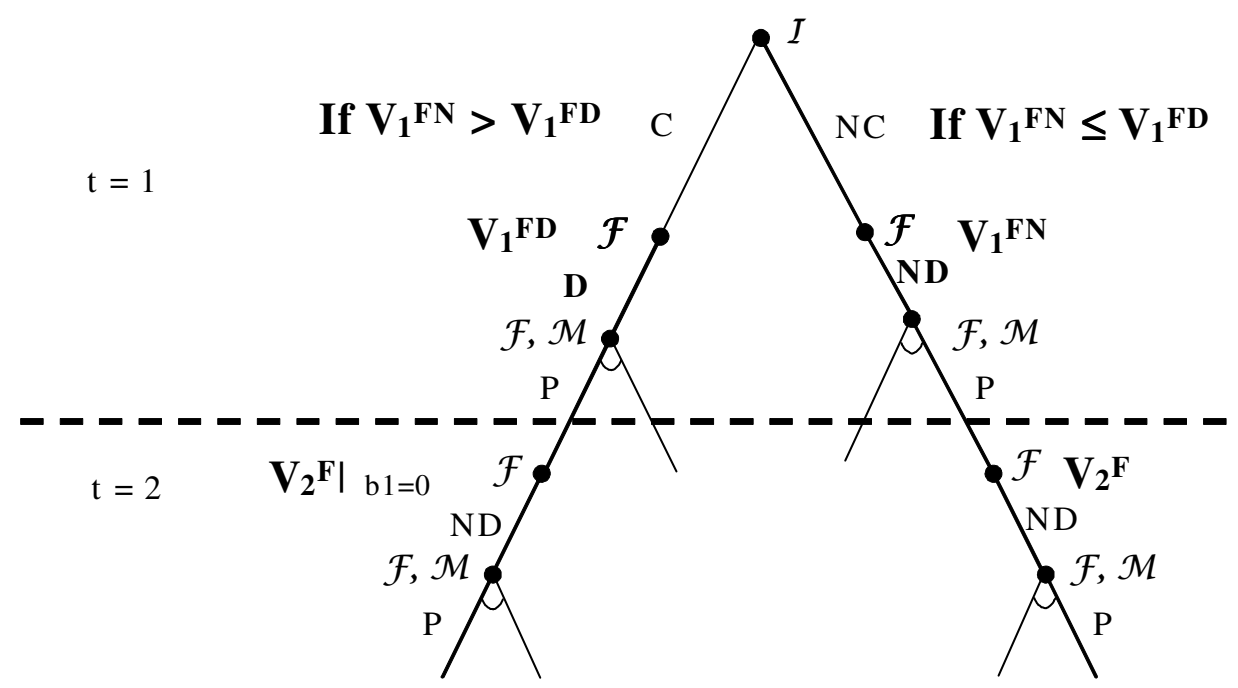

NC: non confidence crisis, C: confidence crisis, D: default, ND: non default, P: policy choice $F$ : fiscal authority, MM: monetary authority, $I$ : investors 
Figure 6

Result of Numerical Analysis in a Realistic Case

\section{Bond to GDP ratio}

Outstanding Bonds

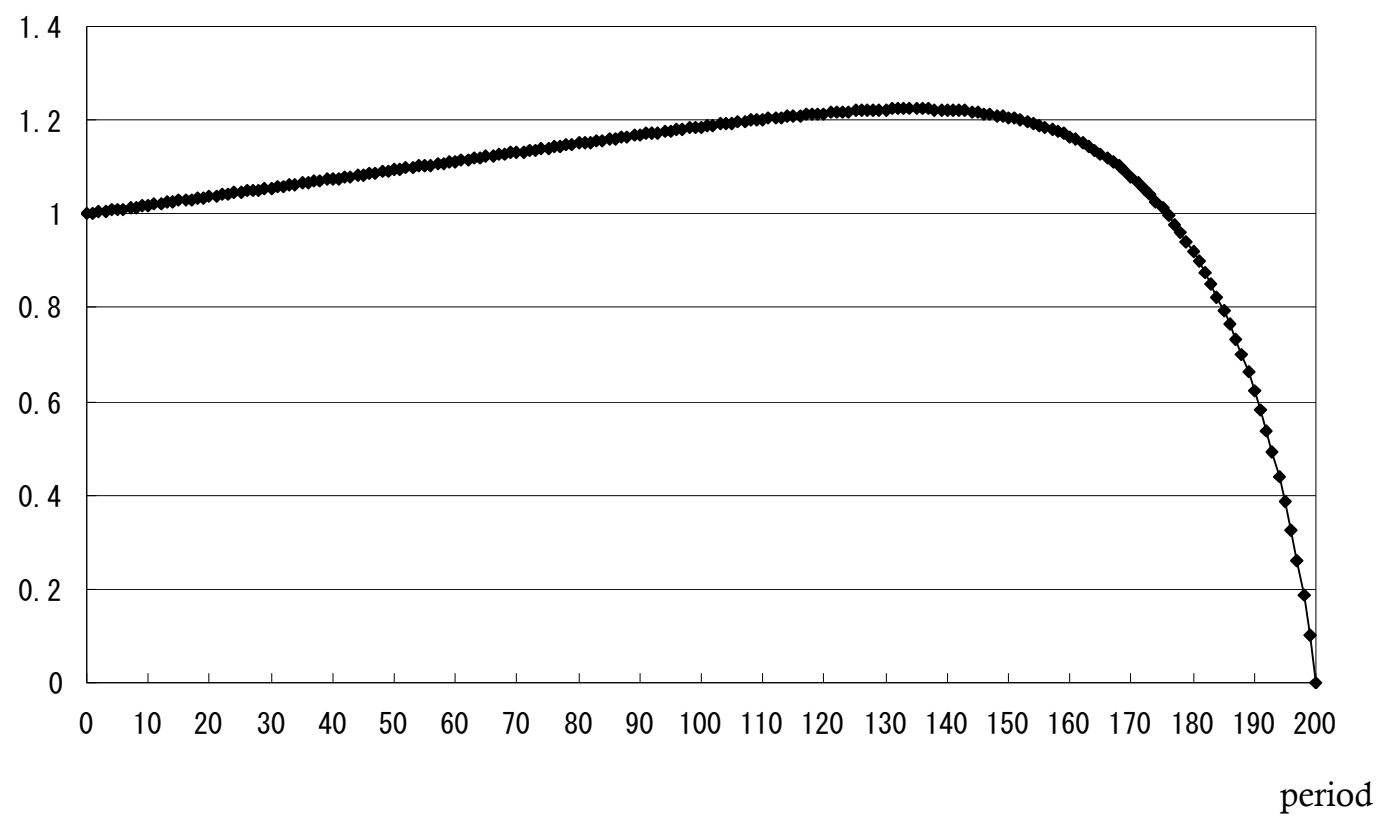

Tax rate, government spending and inflation rate

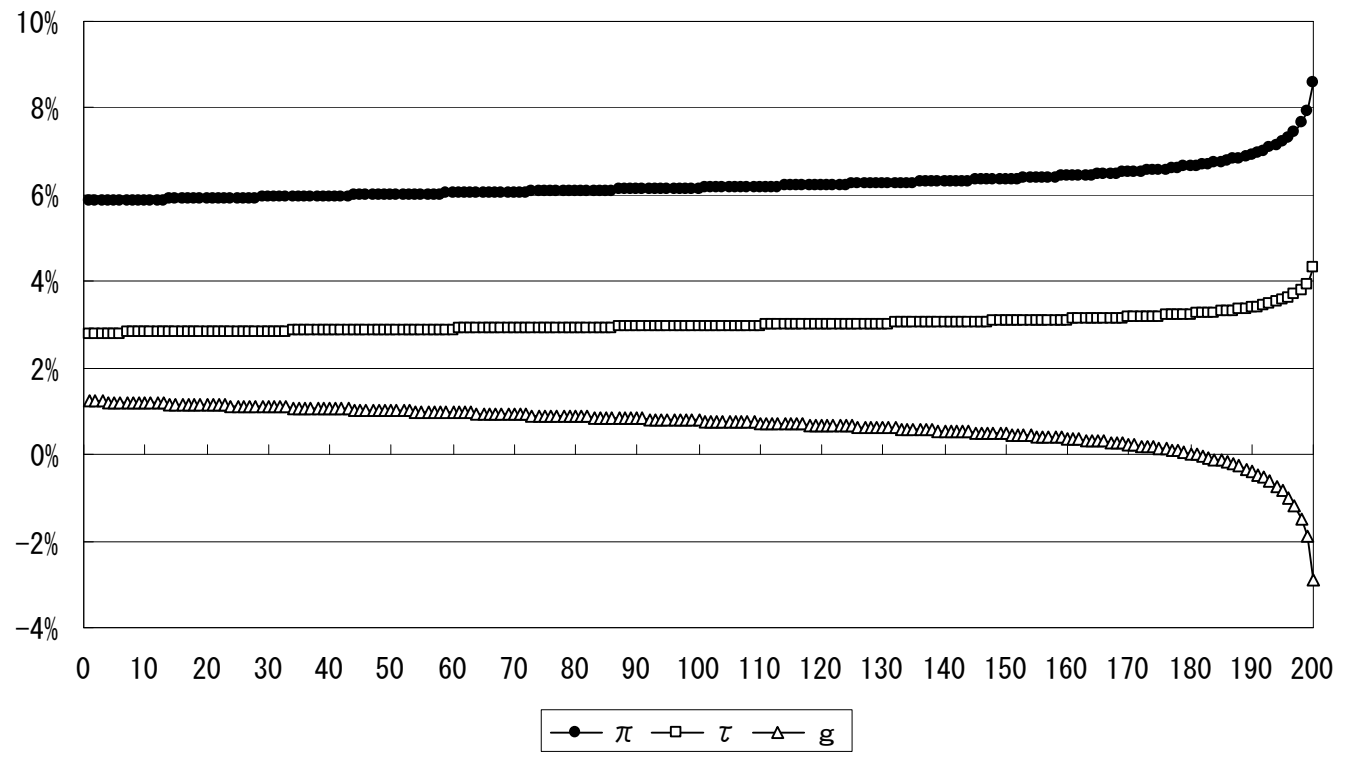

period 
Figure A

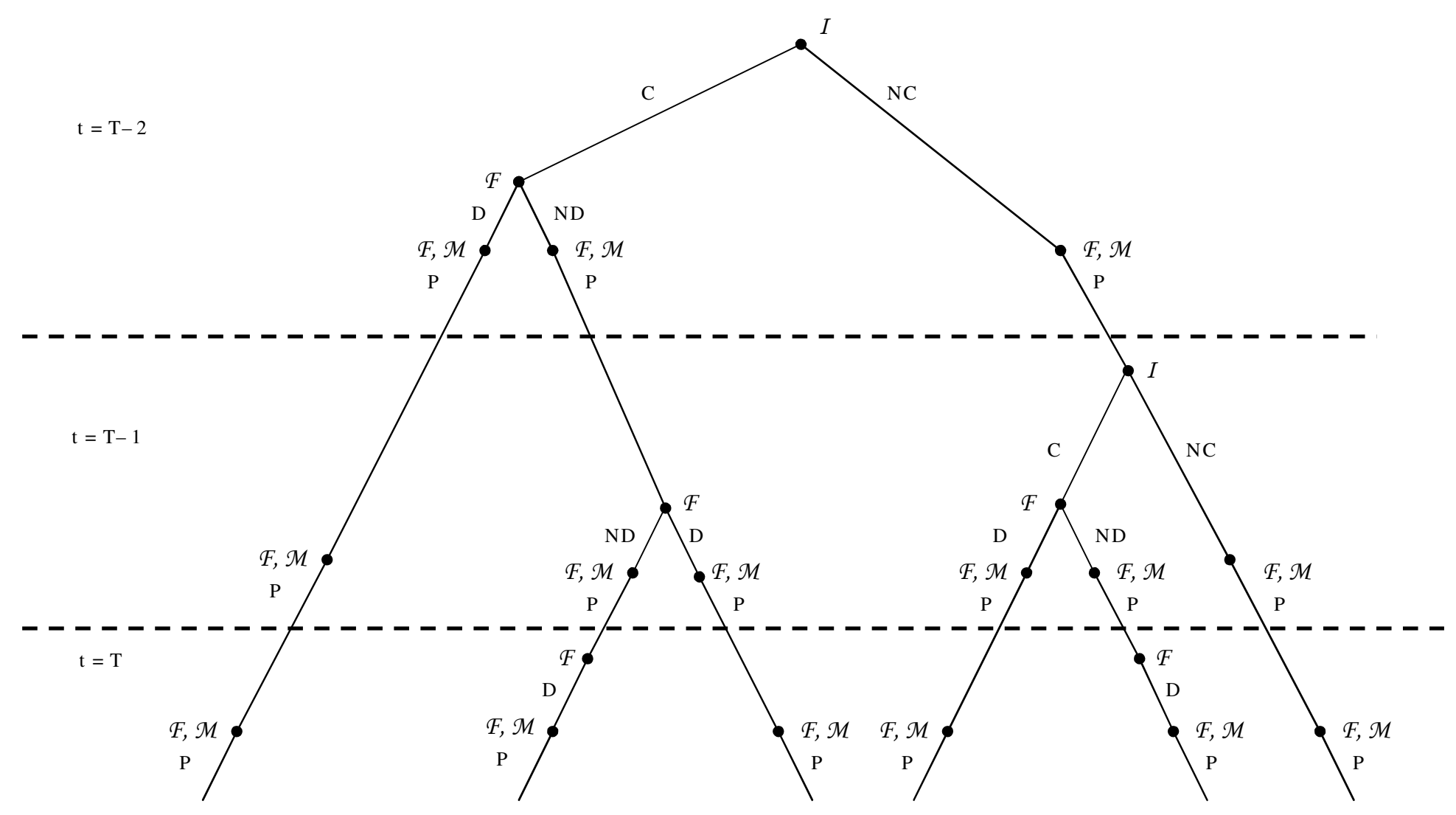

NC: non confidence crisis, C: confidence crisis, D: default, ND: non default, P: policy choice F: fiscal authority, $\mathcal{M}$ : monetary authority, $I$ : investors 
Table 1

Planned Issuance of Japanese Government Bonds

Classification by Issuance Methods and Maturity

\begin{tabular}{|c|c|c|c|}
\hline & $\begin{array}{c}\text { FY2005 } \\
\text { Initial } \\
\text { Budget (a) }\end{array}$ & $\begin{array}{c}\text { FY2006 } \\
\text { Initial } \\
\text { Budget (b) }\end{array}$ & (b) $-(\mathrm{a})$ \\
\hline 30-year Bonds & $2,000.0$ & $2,000.0$ & 0.0 \\
\hline 20-year Bonds & $9,000.0$ & $10,300.0$ & $1,300.0$ \\
\hline 15-year Floating-rate Bonds & $9,600.0$ & $9,100.0$ & -500.0 \\
\hline 10-year Bonds & $22,800.0$ & $24,000.0$ & $1,200.0$ \\
\hline 10-year Inflation-Indexed Bonds & $2,000.0$ & $2,000.0$ & 0.0 \\
\hline 5-year Bonds & $24,000.0$ & $25,200.0$ & $1,200.0$ \\
\hline 2-year Bonds & $20,400.0$ & $21,600.0$ & $1,200.0$ \\
\hline Treasury Bills & $29,961.5$ & $28,719.7$ & $-1,241.8$ \\
\hline Auction for Enhanced-liquidity & - & 600.0 & 600.0 \\
\hline Subtotal & $119,761.5$ & $123,519.7$ & $3,758.2$ \\
\hline Non-price Competitive Auction II & - & $2,658.0$ & $2,658.0$ \\
\hline Amount to the Market & $119,761.5$ & $126,177.7$ & $6,416.2$ \\
\hline JGBs for Individual Investors & $3,600.0$ & $4,400.0$ & 800.0 \\
\hline Amount to Private Sector (x) & $123,361.5$ & $130,577.7$ & $7,216.2$ \\
\hline Bank of Japan & $23,043.6$ & $16,557.4$ & $-6,486.2$ \\
\hline Fiscal Loan Fund & $1,000.0$ & - & $-1,000.0$ \\
\hline $\begin{array}{l}\text { Fiscal Loan Bonds } \\
\text { (transitional measures) }\end{array}$ & $19,300.0$ & $15,200.0$ & $-4,100.0$ \\
\hline OTC sales at Post Offices & $2,800.0$ & $3,100.0$ & 300.0 \\
\hline Amount to Public Sector (y) & $46,143.6$ & $34,857.4$ & $-11,286.2$ \\
\hline TOTAL $\quad(\mathrm{x})+(\mathrm{y})$ & $169,505.1$ & $165,435.1$ & $-4,070.0$ \\
\hline
\end{tabular}

Note

1: Figures may not sum up to the total because of rounding.

2: The amount of buy-backs will be 12,800 billion yen in FY2006 (5,500 billion yen from the Bank of Japan, 5,500 billion yen from the Fiscal Loan Fund and 1,800 billion yen from the market).

3: The limit of interest-rate swap transactions will be 300 billion yen on the basis of notional principal for FY2005, and will be 1,200 billion yen for FY2006.

4: "Non-price Competitive Auction II" is estimated at $3 \%$ of the primary auction.

Source: Ministry of Finance "Planned Bond Issuance for FY 2006" 
Table 2

Maturity Structure of JGBs in Fiscal 2003

\begin{tabular}{|c|c|c|}
\hline & Composition & ratio \\
\hline Maturity & Outstanding & Issuance \\
\hline Years & basis & bas is \\
\hline 1 & $18.78 \%$ & $36.25 \%$ \\
\hline 2 & $13.53 \%$ & $15.86 \%$ \\
\hline 3 & $9.94 \%$ & \\
\hline 4 & $11.22 \%$ & \\
\hline 5 & $12.03 \%$ & $16.23 \%$ \\
\hline 6 & $5.09 \%$ & \\
\hline 7 & $4.79 \%$ & \\
\hline 8 & $4.67 \%$ & \\
\hline 9 & $5.03 \%$ & \\
\hline 10 & $5.01 \%$ & $22.00 \%$ \\
\hline 11 & $0.35 \%$ & \\
\hline 12 & $0.91 \%$ & \\
\hline 13 & $1.39 \%$ & \\
\hline 14 & $1.64 \%$ & \\
\hline 15 & $1.73 \%$ & $4.81 \%$ \\
\hline 16 & $0.41 \%$ & \\
\hline 17 & $0.64 \%$ & \\
\hline 18 & $0.48 \%$ & \\
\hline 19 & $0.75 \%$ & \\
\hline 20 & $0.83 \%$ & $3.78 \%$ \\
\hline 21 & & \\
\hline 22 & & \\
\hline 23 & & \\
\hline 24 & & \\
\hline 25 & & \\
\hline 26 & $0.11 \%$ & \\
\hline 27 & $0.16 \%$ & \\
\hline 28 & $0.07 \%$ & \\
\hline 29 & $0.20 \%$ & \\
\hline 30 & $0.20 \%$ & $1.07 \%$ \\
\hline
\end{tabular}

